\title{
New age constraints for the Salamanca Formation and lower Río Chico Group in the western San Jorge Basin, Patagonia, Argentina: Implications for Cretaceous-Paleogene extinction recovery and land mammal age correlations
}

\begin{abstract}
William C. Clyde ${ }^{1, \dagger}$, Peter Wilf ${ }^{2}$, Ari Iglesias ${ }^{3}$, Rudy L. Slingerland ${ }^{2}$, Timothy Barnum ${ }^{1}$, Peter K. Bijl ${ }^{4}$, Timothy J. Bralower ${ }^{2}$, Henk Brinkhuis ${ }^{4}$, Emily E. Comer ${ }^{2}$, Brian T. Huber ${ }^{5}$, Mauricio Ibañez-Mejia ${ }^{6}$, Brian R. Jicha ${ }^{7}$, J. Marcelo Krause ${ }^{8}$, Jonathan D. Schueth ${ }^{2}$, Bradley S. Singer ${ }^{7}$, María Sol Raigemborn', Mark D. Schmitz ${ }^{10}$, Appy Sluijs ${ }^{4}$, and María del Carmen Zamaloa ${ }^{11}$

${ }^{1}$ Department of Earth Sciences, University of New Hampshire, 56 College Road, Durham, New Hampshire 03824, USA

${ }^{2}$ Department of Geosciences, Pennsylvania State University, University Park, Pennsylvania 16802, USA

${ }^{3}$ División Paleontología, Universidad Nacional del Comahue, Instituto de Investigaciones en Biodiversidad y Ambiente

INIBIOMA-CONICET, San Carlos de Bariloche 8400, Río Negro, Argentina

${ }^{4}$ Department of Earth Sciences, Faculty of Geosciences, Utrecht University Laboratory of Palaeobotany and Palynology,

Budapestlaan 4, 3584 CD Utrecht, The Netherlands

${ }^{5}$ Department of Paleobiology, MRC NHB-121, National Museum of Natural History, Smithsonian Institution, Washington,

District of Columbia 20560, USA

${ }^{6}$ Department of Geosciences, University of Arizona, 1040 E. 4th Street, Tucson, Arizona 85721, USA

${ }^{7}$ Department of Geoscience, University of Wisconsin-Madison, 1215 W. Dayton Street, Madison, Wisconsin 53706, USA

${ }^{8}$ Museo Paleontológico Egidio Feruglio (CONICET-UNPSJB), Av. Fontana 140, 9100 Trelew, Argentina

${ }^{9}$ Centro de Investigaciones Geológicas (CONICET-UNLP), Facultad de Ciencias Naturales y Museo, Universidad Nacional

de La Plata, La Plata 1900, Argentina

${ }^{10}$ Department of Geosciences, Boise State University, 1910 University Drive, Boise, Idaho 83725, USA

${ }^{11}$ Departamento de Ecología, Genética y Evolución, Universidad de Buenos Aires, Capital Federal, Buenos Aires C1428EHA,

Argentina
\end{abstract}

\section{ABSTRACT}

The Salamanca Formation of the San Jorge Basin (Patagonia, Argentina) preserves critical records of Southern Hemisphere Paleocene biotas, but its age remains poorly resolved, with estimates ranging from Late Cretaceous to middle Paleocene. We report a multi-disciplinary geochronologic study of the Salamanca Formation and overlying Río Chico Group in the western part of the basin. New constraints include (1) an ${ }^{40} \mathrm{Ar} /{ }^{39} \mathrm{Ar}$ age determination of $67.31 \pm 0.55$ Ma from a basalt flow underlying the Salamanca Formation, (2) micropaleontological results indicating an early Danian age for the base of the Salamanca Formation, (3) laser ablation HR-MC-ICP-MS (high resolutionmulti collector-inductively coupled plasmamass spectrometry) U-Pb ages and a high-

†E-mail: will.clyde@unh.edu resolution TIMS (thermal ionization mass spectrometry) age of $61.984 \pm 0.041(0.074)$ [0.100] Ma for zircons from volcanic ash beds in the Peñas Coloradas Formation (Río Chico Group), and (4) paleomagnetic results indicating that the Salamanca Formation in this area is entirely of normal polarity, with reversals occurring in the Río Chico Group. Placing these new age constraints in the context of a sequence stratigraphic model for the basin, we correlate the Salamanca Formation in the study area to Chrons C29n and C28n, with the Banco Negro Inferior (BNI), a mature widespread fossiliferous paleosol unit at the top of the Salamanca Formation, corresponding to the top of Chron C28n. The diverse paleobotanical assemblages from this area are here assigned to C28n (64.6763.49 Ma), 2-3 million years older than previously thought, adding to growing evidence for rapid Southern Hemisphere floral recovery after the Cretaceous-Paleogene extinction. Important Peligran and "Carodnia" zone vertebrate fossil assemblages from coastal BNI and Peñas Coloradas exposures are likely older than previously thought and correlate to the early Torrejonian and early Tiffanian North American Land Mammal Ages, respectively.

\section{INTRODUCTION}

During the Paleocene Epoch (66.0-56.0 Ma; Gradstein et al., 2012), the Earth system experienced extreme variability that exposed it to unusual boundary conditions. The base of the Paleocene is characterized by recovery from a bolide impact and mass extinction associated with the Cretaceous-Paleogene (K-Pg) boundary (e.g., Schulte et al., 2010). Paleocene climates were characterized by gradual cooling to minimum values at $60-58 \mathrm{Ma}$, followed by long-term warming (Zachos et al., 2001). The Paleocene ended with the onset of an extreme,

GSA Bulletin; March/April 2014; v. 126; no. 3/4; p. 289-306; doi:10.1130/B30915.1; 10 figures; 2 tables; Data Repository item 2014051;

Published online 21 January 2014. 
yet transient, global warming event called the Paleocene-Eocene Thermal Maximum (PETM), which represents one of the largest perturbations to the carbon cycle of the last 100 million years (Kennett and Stott, 1991; Sluijs et al., 2007; McInerney and Wing, 2011). Understanding the causes and effects of such extreme Earth system variability in the geological past requires wellresolved stratigraphic records from all the major continents and oceans. Although the Paleocene of the South American continent is becoming better documented with respect to fossils and sedimentary environments, the chronostratigraphy of most units is poorly resolved, and thus the associated fossil and sedimentary records cannot be precisely compared to similar records from other parts of the world (Bond et al., 1995; Flynn and Swisher, 1995; Gelfo et al., 2009; Woodburne et al., 2013).

The shallow marine Salamanca Formation is the stratigraphically lowest Cenozoic geological unit in the San Jorge Basin of central Patagonia (Argentina) and has long been studied for its rich fossil record of marine microorganisms (Frenguelli, 1936; Camacho, 1954, 1967; Méndez, 1966; Masiuk, 1967; Bertels, 1975; Matheos et al., 2005), plants (Berry, 1937; Archangelsky, 1973, 1976; Petriella and Archangelsky, 1975; Archangelsky and Zamaloa, 1986; Zamaloa and Andreis, 1995; Matheos et al., 2001; Iglesias et al., 2007; Brea et al., 2008), mammals (Pascual et al., 1992, 2002; Bonaparte et al., 1993; Bonaparte and Morales, 1997; Gelfo and Pascual, 2001; Gelfo, 2007; Gelfo et al., 2007, 2008; Forasiepi and Martinelli, 2003; Gurovich, 2008), reptiles (Bona and de la Fuente, 2005; Bona, 2007; Sterli and de la Fuente, 2012), and marine macrofaunas (Chebli and Serraiotto, 1974; Andreis, 1977; Parma and Casadío, 2005). Despite preserving one of the most complete Paleocene stratigraphic and paleontological records from all of South America, the Salamanca's precise age remains poorly resolved. Some studies have suggested that its base ranges into the Cretaceous (e.g., Legarreta and Uliana, 1994; Gelfo et al., 2009), whereas others indicate that its top ranges up to the late Paleocene (e.g., Foix et al., 2012). Given that the Salamanca Formation is in places less than $50 \mathrm{~m}$ in total thickness, this represents significant chronostratigraphic uncertainty. Understanding the age of the Salamanca is complicated further by the great distances $(>300 \mathrm{~km})$ over which it is exposed and its transgressive character, creating the possibility of significant diachroneity between different parts of the basin.

For this study, we gathered new field data and applied a wide variety of geochronological tools to better date the Salamanca Formation and lower Río Chico Group in the western part of the San Jorge Basin near the city of Sarmiento, where important paleobotanical sites are located (Berry, 1937; Matheos et al., 2001; Iglesias et al., 2007; Fig. 1). We compare these results with previous data from other areas of the basin to better define the time scale of biotic recovery in South America after the K-Pg mass extinction and help constrain the age of other important early Paleogene fossil sites, including vertebrate fossil assemblages known from exposures of these lithologic units farther to the east.

\section{GEOLOGICAL SETTING}

The San Jorge Basin is situated in Chubut and Santa Cruz Provinces of Argentina, between $44^{\circ}$ and $47^{\circ} \mathrm{S}$ and $66^{\circ}$ and $71^{\circ} \mathrm{W}$ (Fig. 1). The basin is bounded by the Somuncura massif to the north, the Deseado massif to the south, the Andean Cordillera to the west, and the continental margin of the Atlantic Ocean to the east (Syl- wan, 2001). Formation of the San Jorge Basin is associated with the Jurassic initial breakup of Gondwana, producing an east-west-oriented extensional intracratonic trough formed on Paleozoic continental crust (Fitzgerald et al., 1990; Spalletti and Franzese, 2007). Infilling of half grabens with volcaniclastic and lacustrine sediments led to the formation of the Jurassic Marifil Complex and Lower Cretaceous Las Heras Group. Continued extension during the rest of the Cretaceous resulted in the deposition of the Chubut Group (Figari et al., 1999; Spalletti and Franzese, 2007; Foix et al., 2012).

The shallow marine Salamanca Formation overlies the Chubut Group, representing a Paleocene transgression of the Atlantic Ocean (Fig. 2). It consists dominantly of sandstones (some glauconitic), siltstones, and mudstones and varies in thickness between $<50 \mathrm{~m}$ to $>150 \mathrm{~m}$ (Feruglio, 1949; Andreis et al., 1975; Matheos et al., 2005; Comer, 2011). Feruglio (1949) recognized four

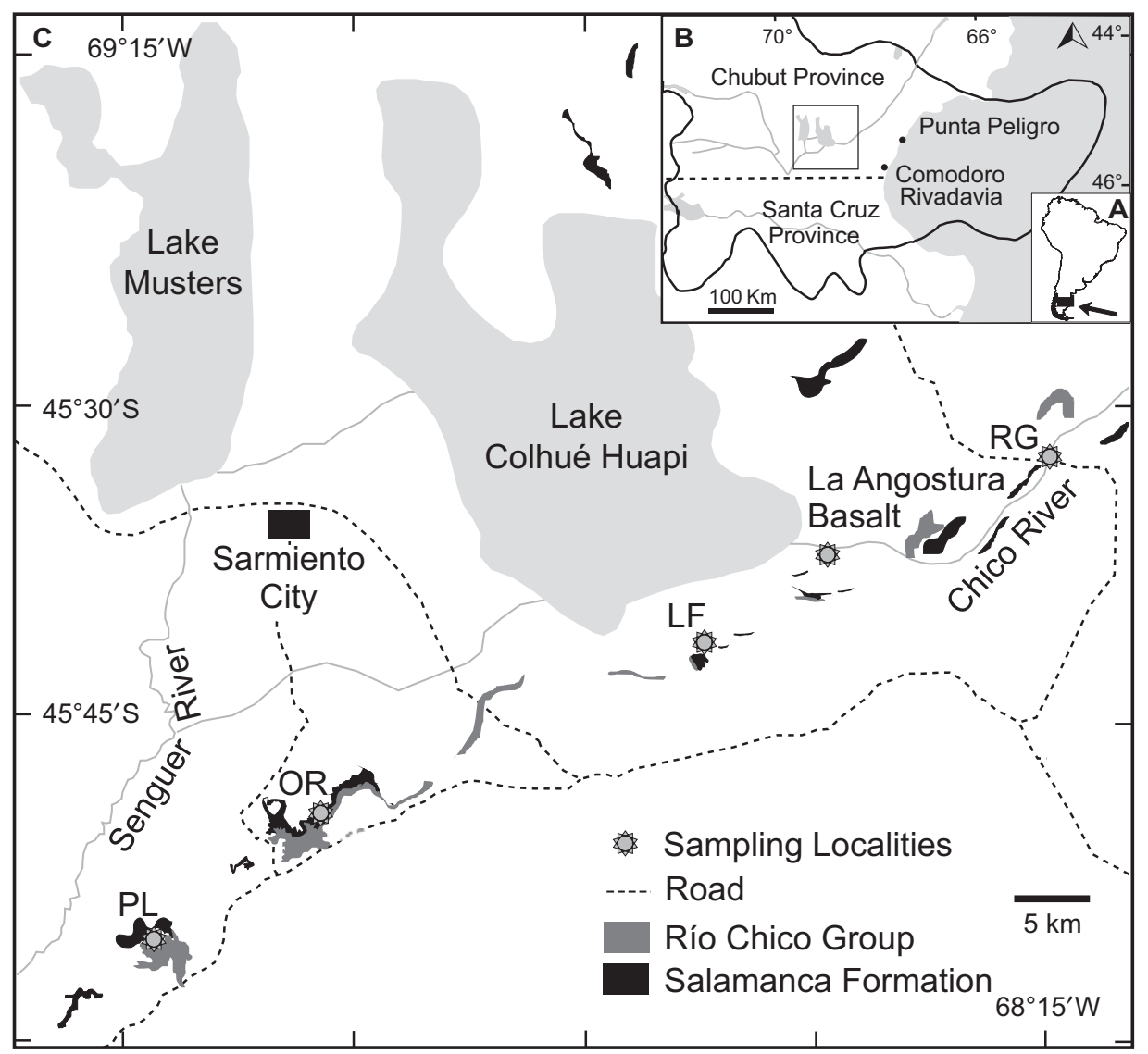

Figure 1. Map showing study area near Sarmiento, Argentina (Patagonia). (A) Map of Argentina showing general location of San Jorge Basin. (B) Map showing approximate outline of San Jorge Basin (dark line) and location of study area (box) as well as other sites mentioned in text. (C) Map of study area showing outcrops of Salamanca Formation and Río Chico Group and location of sampling sites for this study: PL-Palacio de los Loros; OR-Ormaechea; LF_Las Flores; RG_Rancho Grande; La Angostura Basalt_location of basalt sample near Estancia La Angostura that was dated here using ${ }^{40} \mathrm{Ar} /{ }^{39} \mathrm{Ar}$ analyses. 


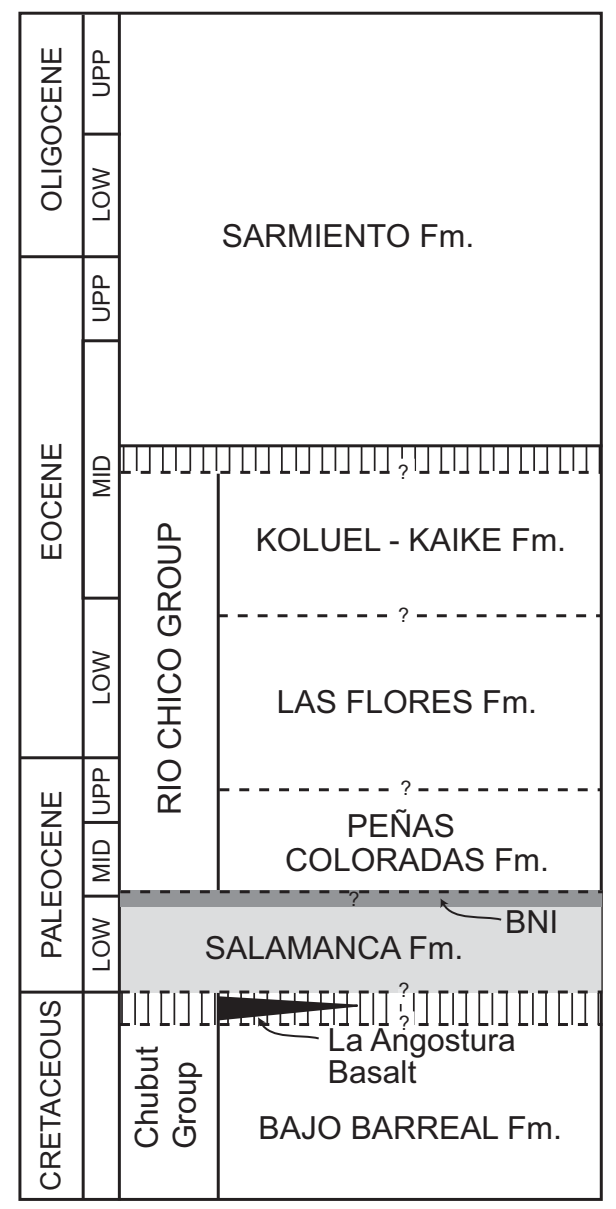

Figure 2. Generalized Late CretaceousPaleogene stratigraphic succession for the study area (after Krause and Piña, 2012). Dashed lines and question marks indicate uncertainty on correlation to the time scale, given information existing before this study. BNI-Banco Negro Inferior.

lithologic units within the Salamanca: Lignitífero, Glauconítico, Fragmentosa, and Banco Verde. Andreis et al. (1975) later divided the Salamanca Formation into a lower Bustamante Member and upper Hansen Member, the latter of which included the Fragmentosa, Banco Verde, and overlying Banco Negro Inferior (BNI), a widespread, dark-colored paleosol unit that marks the transition from shallow marine/estuarine conditions of the Salamanca Formation to continental, fluviolacustrine deposits of the overlying Las Violetas (not exposed in our study area), Peñas Coloradas, Las Flores, and Koluel-Kaike Formations of the Río Chico Group (Feruglio, 1949; Legarreta and Uliana, 1994; Raigemborn et al., 2010). We follow Andreis et al. (1975) and include the BNI in the Salamanca Formation because sedimentological studies indicate that they both formed as part of an overall shallowing- upward, tidally influenced, nearshore-estuarine system with a marine flooding surface at the base and the BNI at the top representing a widespread, prograding coastal swamp (Legarreta and Uliana, 1994; Matheos et al., 2001, 2005; Raigemborn et al., 2010; Comer, 2011).

Several important fossil plant collections have been reported from the Salamanca Formation. These collections include the original, small compression flora from Palacio de los Loros composed of 11 species (Berry, 1937), several palynological and fossil wood studies (Romero, 1968; Archangelsky, 1973; Archangelsky and Romero, 1974; Petriella and Archangelsky, 1975; Archangelsky and Zamaloa, 1986; Brea et al., 2005, 2008; Matheos et al., 2005), and most recently, two large, quantitatively sampled compression floras from the Palacio de los Loros section (Iglesias et al., 2007; Escapa et al., 2013). These last collections show that floral diversity in this part of South America had already risen well above that documented for comparable assemblages in North America by Salamanca time. Also of great interest is that abundant fossil vertebrates are preserved in the BNI along the present-day coast (Pascual et al., 1992, 2002; Bonaparte et al., 1993; Bonaparte and Morales, 1997; Gelfo and Pascual, 2001; Bona and de la Fuente, 2005; Bona, 2007; Gelfo, 2007; Gelfo et al., 2007, 2008; Gurovich, 2008; Sterli and de la Fuente, 2012). The unique mammalian assemblages from the BNI include an immigrant monotreme, non-therians from endemic survivor lineages of the Cretaceous, marsupials, and placentals, thus representing one of the most informative records of vertebrate evolution from the early Paleogene of South America and forming the basis of the Peligran South American Land Mammal Age (SALMA; Bonaparte et al., 1993; Gelfo et al., 2009).

Previous studies of the Salamanca Formation have indicated a mid- to late Danian age (foraminiferal Zone P1C) based on planktonic foraminiferal assemblages found at the Puerto Visser and Punta Peligro localities in the eastern part of the basin, near the modern-day coast (Méndez, 1966; Bertels, 1975). Barcat et al. (1989), however, assigned a Maastrichtian age to the base of the Salamanca Formation based on calcareous nannofossils from a drill hole located in the center of the basin near the coast (Lomita de la Costa). This is based on fossil identifications in an internal oil company report, making them difficult to verify, and the reported taxa are not convincingly age diagnostic. Attempts to refine the age of the Salamanca using radiometric and paleomagnetic techniques have thus far yielded ambiguous results. Marshall et al. (1981) used $\mathrm{K}$-Ar ages of $64.0 \pm 0.8 \mathrm{Ma}$ and $62.8 \pm 0.8 \mathrm{Ma}$ for a basalt flow underneath the base of the Sala- manca (re-dated here) and paleomagnetic data to correlate the BNI to Chron C26r at the Cerro Redondo and Punta Peligro localities along the coast, indicating an approximate age for the BNI of $62 \mathrm{Ma}$. These results were reinterpreted by Bonaparte et al. (1993) who suggested that the BNI correlates to somewhere within Chron C27, with the middle of $\mathrm{C} 27 \mathrm{r}$ as their best estimate. Moreover, Somoza et al. (1995) found the BNI to be characterized by normal polarity at the Las Violetas and El Gauchito localities (north of Cerro Redondo and Punta Peligro on the coast; Fig. 1) and correlated it to Chron C27n. Updated time scales have also significantly changed the estimated ages for the chron boundaries since these original studies were published (Gradstein et al., 2012). In summary, a range of age estimates for the upper and lower limits of the Salamanca Formation (including the BNI) have been proposed, extending from the Maastrichtian to the Selandian (ca. 60-67 Ma).

Results reported here come from the western part of the basin near the city of Sarmiento (Fig. 1). Motivations for working in this area include (1) the presence of macrofloras in the studied sections that appear to be unique on the Gondwanan continents for their combination of early Paleocene age (tested here), excellent preservation and abundance, and unusually high diversity for the time period (Iglesias et al., 2007; Brea et al., 2008), and (2) the need to develop a stratigraphic anchor for the extensive, and long-studied, overlying sequence of Cenozoic vertebrates in the BNI, Río Chico Group, and Sarmiento Formation, which is the richest in the Southern Hemisphere (Ameghino, 1906; Simpson, 1935a, 1935b, 1950, 1980; Madden et al., 2010; Woodburne et al., 2013). Our study is based on (Fig. 1): two adjacent, correlated stratigraphic sections at Bosque Petrificado José Ormaechea (OR; Dromedary Hill and Cerro Colorado); two adjacent, correlated sections at Palacio de los Loros (PLa and PLb); isolated sections of Salamanca Formation at Rancho Grande (RG) and Peñas Coloradas Formation at Las Flores (LF), which each contain important (currently unpublished) macrofloras that extend the knowledge of plant evolution in the region (Iglesias, 2007); and a new isotopic age determination for the basalt near Estancia La Angostura that was first analyzed by Marshall et al. (1981).

\section{METHODS}

\section{Microfossil Biostratigraphy}

\section{Foraminifera}

Samples from the Dromedary Hill section at Ormaechea (OR1013-OR1019) and the Rancho Grande section (RG1001-RG1003) 
were soaked and manually disaggregated in a beaker of tap water, washed over a $63 \mu \mathrm{m}$ sieve, and dried in a convection oven at $50{ }^{\circ} \mathrm{C}$. After initial searches on the picking tray for foraminifera, the sieved residue $(\sim 2-3 \mathrm{~g})$ was poured and stirred in a beaker containing carbon tetrachloride, and the heavy liquid float was decanted into filter paper that, once dried, was scanned to identify and pick biogenic material. Scanning electron microscopy (SEM) was performed on a Phillips XL-30 ESEM with a LaB6 electron source at the U.S. National Museum of Natural History.

\section{Calcareous Nannofossils}

Sample OR1016 was also prepared for analysis of calcareous nannofossils at Pennsylvania State University following Bown and Young (1998). This sample was chosen because SEM images of the planktonic foraminifera showed preserved nannofossils, many in attachment to the studied foraminifera. In addition to the SEM images, small amounts of the sediment were disaggregated and suspended in buffered $(\mathrm{pH}$ $\sim 8$ ) distilled water. This suspension was allowed to settle for 1-2 min for sand- and silt-sized particles to separate from the solution. A microscope slide was made from the resulting suspension, which was observed under cross-polarized light at different magnifications $(1000 \times-1600 \times)$ for at least five random transects of the slide ( $>100$ fields of view) to increase the likelihood of detecting very rare taxa.

\section{Dinoflagellate Cysts}

Twenty palynological samples from all four sections at Ormaechea and Palacio de los Loros were processed for dinoflagellate cysts. Sample processing followed standard protocols of the Laboratory of Palaeobotany and Palynology of Utrecht University (see GSA Data Repository for details ${ }^{1}$.

\section{Terrestrial Palynomorphs}

A set of 24 samples from the four sections at Ormaechea and Palacio de los Loros were processed using standard palynological techniques $\left(\mathrm{HCl}, \mathrm{HF}\right.$, heavy liquid $\mathrm{ZnCl}_{2}$ and $\mathrm{HNO}_{3}$ ) and mounted in polyvinyl alcohol at Universidad de Buenos Aires. Observational and photographic equipment included a Dialux 20 microscope with a Leica EC3 digital camera at the Universidad de Buenos Aires, and a Philips XL 30 scanning electron microscope at the Museo Argentino de Ciencias Naturales "Bernardino Rivadavia". Slides and residues are archived

${ }^{1}$ GSA Data Repository item 2014051, including supplementary methods, figures, and tables, is available at http://www.geosociety.org/pubs/ft2014.htm or by request to editing@ geosociety.org. in the palynological collection of the Departamento de Ecología, Genética y Evolución, Facultad de Ciencias Exactas y Naturales, Universidad de Buenos Aires, as BAFCB p.m. 254-258.

\section{Isotope Geochronology}

\section{${ }^{40} \mathrm{Ar} /{ }^{39} \mathrm{Ar}$}

Marshall et al. (1981) first reported a basalt flow above the Bajo Barreal Formation (Chubut Group), but below the unconformable contact with the Salamanca Formation, in the area along the Río Chico, just east of its outflow from Lake Colhué Huapi (Fig. 1). Whole rock ${ }^{40} \mathrm{~K}-{ }^{40} \mathrm{Ar}$ isotopic geochronology on two samples from this basalt previously yielded ages reported as $64.0 \pm 0.8 \mathrm{Ma}$ and $62.8 \pm 0.8 \mathrm{Ma}$ (Marshall et al., 1981). We resampled this same basalt, here called La Angostura Basalt, in order to determine a modern ${ }^{40} \mathrm{Ar} /{ }^{39} \mathrm{Ar}$ laser incremental heating age for this unit, given its ability to provide a firm maximum age for the Salamanca and the large uncertainties associated with the original ${ }^{40} \mathrm{~K}-{ }^{40} \mathrm{Ar}$ ages. Our sample (LF1007) came from very close to Estancia La Angostura at the outlet of Lake Colhué Huapi (Table DR1). Although we did not observe the contact between the basalt and the overlying Salamanca Formation in this area, subsurface resistivity logs from nearby oil wells are consistent with a laterally discontinuous basalt flow between the Salamanca and underlying Bajo Barreal, supporting the stratigraphic placement shown in Marshall et al. (1981). Samples of purified groundmass were incrementally heated using the methods of Smith et al. (2006). Argon isotope analyses were done using a MAP 215-50 mass spectrometer at the University of Wisconsin, and the data were reduced using ArArCalc software version 2.5 (http://earthref.org/ArArCALC/). The age uncertainties reported here reflect analytical contributions only, at the $2 \sigma$ level; the decay constants used are those of Min et al. (2000; see Supplementary Methods for details).

\section{$U-P b$ LA-ICP-MS}

Three samples from tuff layers within the Peñas Coloradas Formation at Palacio de los Loros (PL-1) and Ormaechea Park (OR-20, OR-21), and one from the upper Salamanca Formation at Ormaechea Park (OR-Tuff-2012.1), were processed for laser ablation-inductively coupled plasma-mass spectrometry (LA-ICPMS) U-Pb geochronology (Table DR1; Fig. DR1). The samples from the Peñas Coloradas Formation at Ormaechea Park were from the same approximate level as those that previously generated an ${ }^{40} \mathrm{Ar} /{ }^{39} \mathrm{Ar}$ isochron age of $57.8 \pm$ 6.0 Ma (Iglesias et al., 2007). Zircons were separated using standard gravimetric and mag- netic techniques, handpicked under a binocular microscope, mounted in epoxy resin, and imaged by cathodoluminescence (SEM-CL) prior to analysis. Isotopic measurements were conducted using a Photon Machines Analyte G2 Excimer ablation system coupled to a Nuinstruments high resolution-inductively coupled plasma-mass spectrometry (HR-MC-ICP-MS) at the Arizona Laserchron Center, University of Arizona, following the methodologies described by Gehrels et al. (2008) and Cecil et al. (2011; see Supplementary Information for details). Systematic uncertainties for the calculated U-Pb ratios were derived from the reproducibility of the measurements made on our Sri Lanka standard. Final ages and uncertainties were calculated using the Isoplot Excel macro of Ludwig (2003), and quoted errors for the age calculations are presented as $\pm \mathrm{X}[\mathrm{Y}]$, where $\mathrm{X}$ refers to the analytical uncertainty only, and $\mathrm{Y}$ represents the analytical and systematic uncertainties combined. Zircons from the Fish Canyon Tuff with an isotope dilution-thermal ionization mass spectrometry (ID-TIMS) age of ca. $28.4 \mathrm{Ma}$ (Schmitz and Bowring, 2001) were analyzed as secondary standards during the same analytical session, where six measurements on three different crystals resulted in a ${ }^{206} \mathrm{~Pb} /{ }^{238} \mathrm{U}$ weighted mean age of $28.3 \pm 0.9 \mathrm{Ma}$ (mean square weighted deviation $[\mathrm{MSWD}]=0.22$ ). Eleven zircon crystals from the PL-1 tuff sample (Fig. DR1A), which is closest to the most productive plant quarry, PL2 (Iglesias et al., 2007), were selected on the basis of their LA-ICP-MS ages and $\mathrm{CL}$ images for additional chemical abrasion-thermal ionization mass spectrometry (CA-TIMS) analyses.

\section{$U-P b C A-T I M S$}

The eleven zircons selected on the basis of the LA-ICP-MS results from the PL-1 tuff sample were subjected to a modified version of the chemical abrasion TIMS method of Mattinson (2005). U-Pb dates and uncertainties were calculated using the algorithms of Schmitz and Schoene (2007) and the U decay constants of Jaffey et al. (1971). Quoted errors are $2 \sigma$ in the form $\pm \mathrm{X}(\mathrm{Y})[\mathrm{Z}]$, where $\mathrm{X}$ is solely analytical uncertainty, $\mathrm{Y}$ is the combined analytical and tracer uncertainty, and $\mathrm{Z}$ is the combined analytical, tracer, and ${ }^{238} \mathrm{U}$ decay constant uncertainty (see Supplementary Methods for additional details).

\section{Paleomagnetism}

Paleomagnetic samples were collected from 60 sample sites within the stratigraphic sections at Ormaechea, Palacio de los Loros, Rancho Grande, and Las Flores. Formations sampled 
included the upper Bajo Barreal (Chubut Group), Salamanca, Peñas Coloradas, and Las Flores. Stepwise alternating field (AF) and thermal demagnetization methods were used on a preliminary set of samples and indicated that AF demagnetization with a peak field of $100 \mathrm{mT}$ was successful at isolating natural remanent magnetization (NRM) components in the majority of samples. However, samples from oxidized red beds within the Río Chico Group were stepwise thermally demagnetized up to $690{ }^{\circ} \mathrm{C}$. Magnetic mineralogy was determined by acquisition of isothermal remanent magnetization (IRM) up to a peak field of $1.1 \mathrm{~T}$, followed by stepwise demagnetization of three orthogonal IRMs of $1.1 \mathrm{~T}, 0.4 \mathrm{~T}$, and $0.12 \mathrm{~T}$ up to $690{ }^{\circ} \mathrm{C}$ (Lowrie, 1990). Paleomagnetic analyses were performed using an HSM2 SQUID cryogenic magnetometer, a Molspin tumbling AF demagnetizer, an ASC Model TD48-SC thermal demagnetizer, and an ASC IM10 impulse magnet in the paleomagnetics lab at the University of New Hampshire.

\section{RESULTS}

\section{Microfossil Biostratigraphy}

\section{Foraminifera}

Extremely rare but very well-preserved foraminifera were found only in samples OR1016 and RG1002 (Table 1). The silty claystone sample OR1016 (basal Salamanca Formation in Ormaechea Park; Table DR2) yielded one benthic foraminifer assigned to Gyroidinoides nitidus (Fig. 3.1) and eight planktonic specimens assigned to Globanomalina planocompressa (6 specimens; Figs. 3.2, 3.4), Dipsidripella? sp. (1 specimen; Fig. 3.3), and one unknown taxon. Co-occurrence of the foraminifera with common tri-radiate sponge spicules, and their extraordinarily good preservation, indicate that these specimens were deposited in situ within a shelfal marine depositional environment. The small sizes of the planktonic foraminifera and the patchy distribution of wall pores in the $G$. planocompressa specimens indicate they did not reach reproductive maturity, which is consistent with the interpretation that they were deposited in a shallow marine setting. In the clay-rich siltstone sample RG1002, several large-sized benthic specimens were found (e.g.,
Fig. DR2), but no planktonic foraminifera or other microfossil constituents were observed. The large (0.4-0.6 mm diameter) and robust shells, absence of shell infilling or recrystallization, and occurrence with silt-sized grains and authigenic glauconite argue that the specimens were not reworked from a significantly older, lithified sediment source. Nonetheless, abrasion of the final chambers may indicate some degree of local sediment reworking. The specimens are tentatively assigned to Cribrorotalia?, but the presence of deeply incised umbilical sutures and raised spiral sutures, as well as the reported stratigraphic age range of this genus from the late Eocene through middle Miocene (Loeblich and Tappan, 1988), suggest this may belong to a different, but related taxon. Nonetheless, this form is characteristic of species found only in shallow, inner to middle shelf paleoenvironments.

The occurrence of $G$. planocompressa in sample OR1016 indicates an early Danian age based on its recorded range from upper planktonic foraminifer Zone P $\alpha$ through middle Zone P1c (Olsson et al., 1999). Although G. planocompressa has not been recorded elsewhere in Patagonia, its occurrence in the Ormaechea section is consistent with reports of Danian planktonic foraminifera, including Parasubbotina pseudobulloides, Subbotina triloculinoides, and Globoconusa daubjergensis, from the Salamanca Formation in the eastern coastal region of Chubut (Méndez, 1966; Masiuk, 1967; Bertels, 1975). Absence of these latter species in OR1016 may have been the result of shallower marine conditions in the shoreward region of the San Jorge Basin, or facies progradation across the basin causing the Salamanca Formation to be somewhat time-transgressive from west to east. Assignment of the specimen illustrated in Figure 3.3 to Dipsidripella? is based on the presence of a strongly muricate wall texture, incised sutures, and extra-umbilical position of the aperture. If this taxonomic placement is correct, this occurrence considerably predates the age range for the oldest species of the genus, Dipsidripella danvillensis, which is from the middle-upper Eocene (Pearson et al., 2006). In summary, the foraminiferal data from sample OR1016 in the lower Salamanca Formation at Ormaechea indicate an early Danian age (Zone $\mathrm{P} \alpha$-middle Zone P1c).

\section{Calcareous Nannofossils}

Nannofossils are present but very rare and poorly preserved in sediment sample OR1016. Calcisphere (thoracosphere) fragments were the most commonly observed nannofossils (Fig. DR3A). Coccolithus cavus, Cruciplacolithus primus, and Prinsius dimorphosus are also present at very rare abundances (Figs. DR3B-DR3D respectively; Table 1). The presence of these taxa indicates an early Danian age for the sediment, likely in the NP2 biozone (Martini, 1971). Nannofossils observed in the SEM micrographs also support the early Danian age assessment. Although distinct nannofossil biostratigraphic indicator taxa are lacking in these images, Zeugrhabdotus sigmoides, Cyclagelosphaera sp., and Biscutum sp. were observed (Figs. DR3EDR3F), all known K-Pg survivors (e.g., Bown, 2005). Several securely Cretaceous taxa are also present in the SEM micrographs, including Nephrolithus frequens and Staurolithites (Fig. DR3F). However, the lack of other important Cretaceous biomarkers and greater abundance of known K-Pg survivors suggest that the Cretaceous-type nannofossils were reworked. Overall, the nannofossils from sample OR1016, lower Salamanca Formation at Ormaechea Park, are most consistent with an early Danian age (NP2 biozone) and also contain a reworked Cretaceous component.

\section{Dinoflagellate Cysts}

Of the 20 samples processed for dinocysts, only two were productive. Sample OR1016 contains, along with pollen and spores (see next section), an abundant and diverse dinocyst assemblage. Age-diagnostic species include Cyclapophysis monmouthensis, Senoniasphaera inornata, Damassadinium californicum, Trithyrodinium evittii, and Palaeoperidinium pyrophorum (Table 1; Fig. DR4). These species together are typical for earliest Danian strata worldwide (Williams et al., 2004). Other species present in this sample are Lentinia sp., Cerodinium sp., Palaeocystodinium golzowense, Areoligera tauloma, Glaphyrocysta pastielsii, Tanyosphaeridium sp., and Spiniferites sp. The abundant dinocysts in sample OR1016 comprise an assemblage that is typical for an earliest Danian marine shelf (Pross and Brinkhuis, 2005) and suggest a major transgression in this area by the earliest Danian (Scasso et al., 2012). Normal marine conditions prevailed, however nutrient

TABLE 1. BIOSTRATIGRAPHICALLY SIGNIFICANT MICROFOSSILS RECOVERED FROM THE BASAL SALAMANCA FORMATION NEAR SARMIENTO, ARGENTINA, INDICATING AN EARLY DANIAN AGE

\begin{tabular}{|c|c|c|c|}
\hline ample & Dinoflagellates & Foraminifera & Calcareous nannofossils \\
\hline 21016 & $\begin{array}{l}\text { Senoniasphaera inornata, Cyclapophysis monmouthensis, } \\
\text { Damassadinium californicum, Trithyrodinium evittii, } \\
\text { Palaeoperidinium pyrophorum, Tanyosphaeridium, Spiniferites, } \\
\text { Cerodinium, Lentinia, Palaeocystodinium }\end{array}$ & $\begin{array}{l}\text { Gyroidinoides nitidus, Dipsidripella } \\
\text { sp., Globanomalina } \\
\text { planocompressa }\end{array}$ & $\begin{array}{l}\text { Coccolithus cavus, Cruciplacolithus primus, } \\
\text { Prinsius dimorphosus, Zeugrhabdotus sigmoides, } \\
\text { Cyclagelosphaera, Biscutum, Nephrolithus frequens, } \\
\text { Staurolithites }\end{array}$ \\
\hline
\end{tabular}




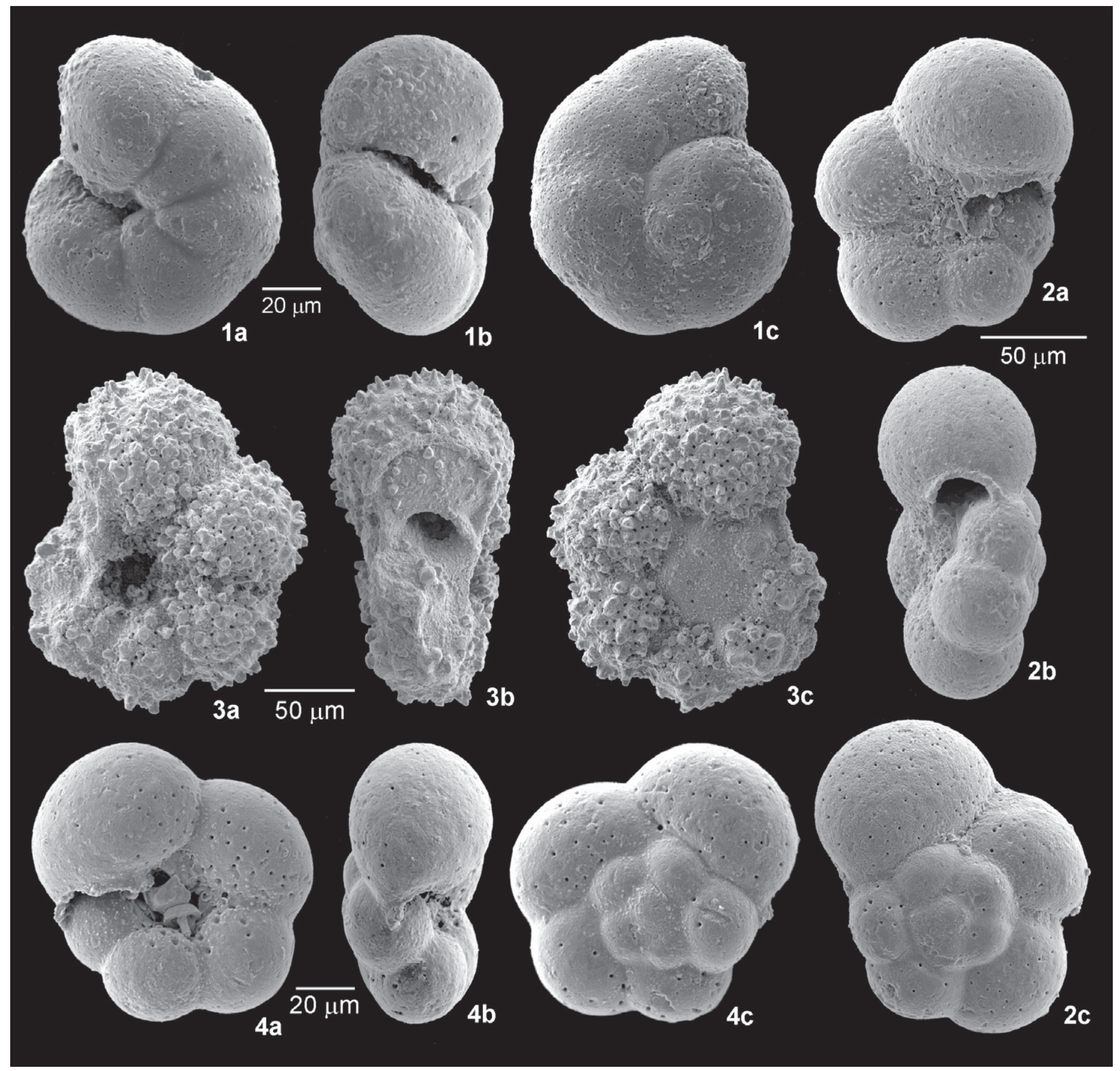

Figure 3. Early Paleocene foraminifera from sample OR1016, showing umbilical, edge, and spiral views. Planktonic specimens are probably juveniles, as evidenced by their small size and widely and unevenly scattered wall pores. (1a-1c) Benthic foraminifer Gyroidinoides nitidus (Reuss). (2a-2c) Planktonic foraminifer Globanomalina planocompressa (Shutskaya, 1965). (3a-3c) Planktonic foraminifer Dipsidripella? sp. (4a-4c) Planktonic foraminifer Globanomalina planocompressa (Shutskaya, 1965).

input was probably large given the relatively high abundance of (presumed heterotrophic) peridinioid dinocysts, such as Cerodinium, Lentinia, and Palaeocystodinium compared to (presumed autotrophic) gonyaulacoid cysts (Sluijs et al., 2005). Sample PL1019 (basal Peñas Coloradas Formation, Palacio de los Loros; Table
DR2) is dominated by terrestrial palynomorphs and the green alga Pediastrum (see next section), but the dinocyst Senegalinium is also common. In this sample, the abundant pollen and spores in combination with the high abundance of Pediastrum suggest a high input of terrestrial and aquatic organic matter, but the presence of
Senegalinium suggests continued marine influence, albeit at low salinities (Brinkhuis et al., 2006; Sluijs and Brinkhuis, 2009). The absence of dinocysts in all other samples is probably due to syndepositional overexposure to oxygen and physical abrasion associated with very shallow or non-marine environments. 


\section{Terrestrial Palynomorphs}

Six of the 24 samples yielded terrestrial palynomorphs, and five of those had abundant, diverse, and well-preserved palynofloras (Table 2, Fig. 4). A total of 63 pollen and spore taxa were recognized. Angiosperm pollen was highly diverse at all levels examined and represents more than $50 \%$ of the total taxa; pteridophyte and bryophyte spores represent $\sim 30 \%$ and gymnosperm (conifer) pollen represents $\sim 13 \%$. In spite of the relatively low diversity of conifers, two different species (and probably new species) of Classopollis (Figs. 4E-4F), pollen produced by members of the extinct family Cheirolepidiaceae, are the most abundant type in almost all the assemblages and dominate in samples PL1011 and OR1015-OR1017. Green algae were observed at two levels: cenobia of Pediastrum boryanum (Turp.) Menegh in PL1011 (also noted in the previous section for sample PL1019) and Zygnemataceae spores in OR1015.

Pollen and spores of the Salamanca Formation from other locations are known from several earlier studies (Archangelsky, 1973, 1976; Archangelsky and Romero, 1974; Archangelsky and Zamaloa, 1986; Zamaloa and Andreis, 1995; Scafati et al., 2009), but the data reported here are placed in a greatly improved chronologic framework and thus have increased biostratigraphic usefulness. The samples analyzed here contain many previously known palynomorphs as well as a few taxa that are recorded for the first time in the Salamanca Formation (Table 2). Two of these new records, Pediastrum cenobia and Kuylisporites waterbolkii Potonié spores, are of particular interest. The presence of $P$. boryanum in PL1011 indicates a freshwater paleoenvironment at the time of growth (Batten, 1996), although these algal remains are also found in sediments deposited on or beyond the marine continental shelf as part of allochthonous associations brought by streams from inland areas (Brenac and Richards, 1996). Additionally, the presence of representatives of Zygnemataceae (in OR1015) indicates depositional conditions of shallow, stagnant, clean, freshwater lakes or ponds (van Geel and Grenfell, 1996). Spores of $K$. waterbolkii closely resemble those produced by extant species of Cnemidaria Presl. (Cyatheaceae). These tree ferns grow today in Central America, the Greater Antilles, and northern South America (Tryon et al., 1982). The known fossil record of Cnemidaria-type spores indicates a wide Gondwanan distribution (except for Africa) during the Cenozoic. They were present in Australia and New Zealand from the Eocene to the Miocene, in Antarctica during the middle Eocene (Mohr and Lazarus, 1994), and in Tierra del Fuego in sediments of questionable Eocene age (Zetter et al., 1999). The Salamanca Formation record represents the oldest known worldwide for the species. Additionally, according to Mohr and Lazarus (1994, p. 765), K. waterbolkii is an "indicator of warm-temperate, not fully tropical climate." As Archangelsky and Romero (1974) pointed out, the presence of Classopollis pollen in sediments of the Salamanca Formation represents the last record for the genus in Patagonia, a statement that has been confirmed by more recent studies in several basins of the region, including a similar "Classopollis spike" found in early Danian littoral sediments of the Lefipán Formation in northwestern Chubut (Barreda et al., 2012). The high palynological diversity and good preservation of the analyzed assemblages indicate a local source of the pollen and spores, which were produced by trees, shrubs, and herbs growing inland and near the shore. The mixture of the aquatic components (green algae) and marine dinoflagellates is consistent with an estuarine or other river-influenced shallow shelf environment for the Salamanca (Comer, 2011).

\section{Isotope Geochronology}

\section{${ }^{40} \mathrm{Ar} /{ }^{39} \mathrm{Ar}$}

The incremental heating experiment on the sample LF1007 from the basalt intercalated between the Bajo Barreal and Salamanca Formations yielded a well-defined plateau with a weighted mean age of $66.95 \pm 0.37 \mathrm{Ma}$, which comprises $\sim 97 \%$ of the ${ }^{39} \mathrm{Ar}$ released (Fig. 5; Table DR3). The initial five heating steps of the experiment gave ages that were slightly younger, possibly indicating a small degree of radiogenic argon loss. The 17-step isochron defined an age of $67.31 \pm 0.55 \mathrm{Ma}$ with a MSWD of 0.31 and an initial ${ }^{40} \mathrm{Ar} /{ }^{36} \mathrm{Ar}$ ratio of $294.7 \pm 0.9$. This isochron age is preferred, rather than the apparent plateau age, because it takes into account the potential for a non-atmospheric trapped component. This ${ }^{40} \mathrm{Ar} /{ }^{39} \mathrm{Ar}$ age $(67.31 \pm 0.55 \mathrm{Ma})$ for the La Angostura basalt is significantly older than the K-Ar dates previously reported for the same unit $(64.0 \pm 0.8 \mathrm{Ma}$ and $62.8 \pm 0.8 \mathrm{Ma}$; Marshall et al., 1981), probably reflecting inaccurate measurement of ${ }^{40} \mathrm{Ar}^{*}$ or $\mathrm{K}$ content of the extremely large whole-rock samples that were melted for the original K-Ar analyses.

\section{$U-P b$ LA-ICP-MS}

Results from the twenty zircons that were analyzed from each of the tuff samples using the LA-ICP-MS method are shown in Table DR4. Calculated ages for Peñas Coloradas Formation samples from the PL-1 (Palacio de los Loros), OR-20, and OR-21 (Ormaechea) tuffs all overlapped within analytical uncertainty, thus supporting the idea that they represent coeval phases of volcanism in these two, 15.4-km-apart sampling areas and provide an important new chronostratigraphic marker. The age of igneous crystallization for the PL-1 tuff was estimated by this method to $61.48 \pm 0.66$ [0.82] Ma from 19 equivalent ${ }^{206} \mathrm{~Pb} /{ }^{238} \mathrm{U}$ dates (MSWD $=0.26$; Fig. 6A), later refined by the CA-TIMS analyses discussed below. The OR-20 tuff yielded an age of $62.08 \pm 0.83[0.98] \mathrm{Ma}(\mathrm{n}=16 ; \mathrm{MSWD}=0.41$; Fig. 6C), while that of OR-21 was estimated to $61.51 \pm 0.88$ [1.00] Ma $(n=16 ;$ MSWD = 0.34; Fig. 6D). The sample from the upper Salamanca Formation at Ormaechea (OR-Tuff-2012.1) had zircons with a wide range of calculated ages from 67.9 to $194.6 \mathrm{Ma}$, with two main clusters of 100-120 Ma and 140-150 Ma (Fig. DR5). These results for OR-Tuff-2012.1 are consistent with the zircons in this sample being detrital in origin, thus providing sedimentary provenance information for the Salamanca Formation rather than direct geochronological constraints. The younger cluster of zircons is consistent with a source in the lower part of the underlying Cretaceous Chubut Group, and the older, Late Jurassic-Early Cretaceous cluster could be associated with unroofing of arc volcanic rocks far to the west (Barcat et al., 1989; Sylwan, 2001; Spalletti and Franzese, 2007).

\section{U-Pb CA-TIMS}

Of the 11 zircon crystals from the PL-1 tuff that were chosen based on their LA-ICP-MS ages and CL images, three grains yielded resolvably older ages (Table DR5) interpreted as having a contribution from cores of significantly older, xenocrystic zircon (z3) or only slightly older antecrystic zircon (z2, z8). Equivalent ${ }^{206} \mathrm{~Pb} /{ }^{238} \mathrm{U}$ dates were obtained from the remaining eight crystals (Fig. 6B). The age of igneous crystallization for the PL-1 tuff (Peñas Coloradas Formation at Palacio de los Loros) may be interpreted from the weighted mean ${ }^{206} \mathrm{~Pb} /{ }^{238} \mathrm{U}$ date to be $61.984 \pm 0.041(0.074)[0.100] \mathrm{Ma}$ $(\mathrm{n}=8 ; \operatorname{MSWD}=0.75)$.

\section{Paleomagnetism}

The acquisition of IRM in samples from the Salamanca Formation (OR1016 and OR1019) and Banco Negro Inferior (OR1022) showed rapid increases in intensity with saturation occurring around $0.2 \mathrm{~T}$, indicating that the magnetic mineralogy is dominated by a lowcoercivity mineral like magnetite or greigite (Fig. DR6A). Demagnetization curves showed a gradual decrease in intensity with final unblocking temperatures of $580^{\circ} \mathrm{C}$, suggesting that magnetite is the dominant carrier of magnetic remanence in these samples (Figs. DR6B-DR6D). 


\begin{tabular}{|c|c|c|c|c|c|}
\hline Sample & PL1002 & PL1011 & OR1015 & OR1016 & OR1023 \\
\hline$\left.\underline{\text { Section/level }}\right|^{+}$ & $\mathrm{PL}(\mathrm{a}) / 1.4 \mathrm{~m}$ & $\mathrm{PL}(\mathrm{a}) / 30.4 \mathrm{~m}$ & $\mathrm{DH} / 3.3 \mathrm{~m}$ & $\mathrm{DH} / 5.1 \mathrm{~m}$ & $\mathrm{CC} /-8.3 \mathrm{~m}$ \\
\hline \multicolumn{6}{|l|}{ Bryophytes/pteridophytes } \\
\hline 1. Ceratosporites equalis Cookson \& Dettmann 1958 & $\mathrm{x}$ & & & $\mathrm{x}$ & $\mathrm{x}$ \\
\hline 2. Cicatricosisporites sp.* ${ }^{*}$ & & & & $\mathrm{x}$ & \\
\hline 3. Cingutriletes australis (Cookson) Archangelsky 1972 & & & & & $\mathrm{x}$ \\
\hline 4. Clavifera triplex (Bolkhovitina) Bolkhovitina 1966 & $\mathrm{x}$ & & & $\mathrm{x}$ & $\mathrm{x}$ \\
\hline 5. Kuylisporites waterbolkii Potonié $1956^{\star}$ & & $\mathrm{x}$ & & & \\
\hline 6. Cyathidites minor Couper 1953 & & & $\mathrm{x}$ & $\mathrm{x}$ & $\mathrm{x}$ \\
\hline 7. Cyathidites patagonicus Archangelsky 1972 & $\mathrm{x}$ & & $\mathrm{x}$ & & \\
\hline 8. Dictyophyllidites concavus Harris 1965 & & & $\mathrm{x}$ & $\mathrm{x}$ & $\mathrm{x}$ \\
\hline 9. Gleichenidites sp. & $\mathrm{x}$ & & & & \\
\hline 10. Laevigatosporites ovatus Wilson \& Webster 1946 & & & $\mathrm{x}$ & & $\mathrm{x}$ \\
\hline 11. Retitriletes austroclavatidites (Cookson) Doring et al. in Krutzsch 1963 & & & & & $\mathrm{x}$ \\
\hline 12. Polypodiidites speciosus (Harris) Archangelsky $1972^{\star}$ & & & & & $\mathrm{x}$ \\
\hline 13. Stereisporites antiquasporites (Wilson \& Webster) Dettmann 1963 & & & & & $\mathrm{x}$ \\
\hline 14. Trilites parvalatus Krutzsch 1959 & & & $\mathrm{x}$ & $\mathrm{x}$ & $\mathrm{x}$ \\
\hline 15. Trilete verrucate* ${ }^{*}$ & & & & & $\mathrm{x}$ \\
\hline 16. Trilete wth perisporium* & & & & $\mathrm{x}$ & \\
\hline 17. Trilete $2^{*}$ & & & $\mathrm{x}$ & & \\
\hline 18. Trilete $3^{*}$ & & & & & $\mathrm{x}$ \\
\hline \multicolumn{6}{|l|}{ Gymnosperms } \\
\hline 1. Classopollis spp. & $\mathrm{x}$ & & $\mathrm{x}$ & $\mathrm{x}$ & $\mathrm{x}$ \\
\hline 2. Dacrydiumites praecupressinoides (Couper) Truswell 1983 & & $\mathrm{x}$ & $\mathrm{x}$ & $\mathrm{x}$ & $\mathrm{x}$ \\
\hline 3. Microcachrydites antarcticus Cookson 1947 & & & $\mathrm{x}$ & $\mathrm{x}$ & $\mathrm{x}$ \\
\hline 4. Phyllocladidites mawsonii Cookson ex Couper $1953^{*}$ & & & & & $\mathrm{x}$ \\
\hline 5. Podocarpidites elegans Romero 1977 & $\mathrm{x}$ & & $\mathrm{x}$ & $\mathrm{x}$ & $\mathrm{x}$ \\
\hline 6. Podocarpidites marwickii Couper 1953 & $\mathrm{x}$ & & $\mathrm{x}$ & $\mathrm{x}$ & \\
\hline 7. Podocarpidites rugulosus Romero 1977 & & $\mathrm{x}$ & $\mathrm{x}$ & $\mathrm{x}$ & $\mathrm{x}$ \\
\hline 8. Trichotomosulcites subgranulatus Couper 1953 & $\mathrm{x}$ & & & $\mathrm{x}$ & $\mathrm{x}$ \\
\hline \multicolumn{6}{|l|}{ Angiosperms } \\
\hline 1. Ailanthipites cf marginatus Frederiksen $1983^{*}$ & & & $\mathrm{x}$ & & \\
\hline 2. Arecipites minutiscabratus (Mclntyre) Milne 1988 & $\mathrm{x}$ & & & & $\mathrm{x}$ \\
\hline 3. Haloragacidites sp. & & & $\mathrm{x}$ & $\mathrm{x}$ & \\
\hline 4. Liliacidites variegatus Couper 1953 & & & $\mathrm{x}$ & $\mathrm{x}$ & \\
\hline 5. Liliacidites vermireticulatus Archangelsky and Zamaloa 1986 & $\mathrm{x}$ & & $\mathrm{x}$ & & \\
\hline 6. Myrtaceidites sp. & & & & & $\mathrm{x}$ \\
\hline 7. Nothofagidites dorotensis Romero 1973 & & & $\mathrm{x}$ & & \\
\hline 8. Nothofagidites saraensis Menendez y Caccavari 1975 & & & & & $\mathrm{x}$ \\
\hline 9. Peninsulapollis gillii (Cookson) Dettmann \& Jarzen 1988 & & $\mathrm{x}$ & $\mathrm{x}$ & $\mathrm{x}$ & $\mathrm{x}$ \\
\hline 10. Peninsulapollis sp. & & & $\mathrm{x}$ & & \\
\hline 11. Proteacidites sp. $\mathrm{A}^{*}$ & & & & $\mathrm{x}$ & $\mathrm{x}$ \\
\hline 12. Proteacidites sp. $\mathrm{B}^{*}$ & & & & $\mathrm{x}$ & $\mathrm{x}$ \\
\hline 13. Proteacidites $\mathrm{sp}$. $\mathrm{C}^{*}$ & & & & & $\mathrm{x}$ \\
\hline 14. Proteacidites cf. fromensis Harris $1972^{\star}$ & & & & & $\mathrm{x}$ \\
\hline 15. Proxapertites sp. & & $\mathrm{x}$ & $\mathrm{x}$ & $\mathrm{x}$ & $\mathrm{x}$ \\
\hline 16. Psilatricolporites sp. & & & $\mathrm{x}$ & $\mathrm{x}$ & \\
\hline 17. Restioniidites pascualii Archangelsky 1973 & & & $\mathrm{x}$ & $\mathrm{x}$ & \\
\hline 18. Rhoipites baculatus Archangelsky 1973 & & & & $\hat{x}$ & \\
\hline 19. Rousea microreticulata Archangelsky and Zamaloa 1986 & & & & & $\mathrm{x}$ \\
\hline 20. Senipites tercrassata Archangelsky 1973 & & & & & $\mathrm{x}$ \\
\hline 21. Tetrade reticulate ${ }^{*}$ & & & & & $\mathrm{x}$ \\
\hline 22. Tricolporate prolate sincolpate* & & & & & $\mathrm{x}$ \\
\hline 23. 5-6 colporate prolate & & & & & $\mathrm{x}$ \\
\hline 24. Triatriopollenites lateflexus Archangelsky 1973 & & & $\mathrm{x}$ & & $\mathrm{x}$ \\
\hline 25. Tricolpites anguloluminosus Anderson 1960 & & & $\mathrm{x}$ & $\mathrm{x}$ & \\
\hline 26. Tricolpites communis Archangelsky 1973 & $\mathrm{x}$ & & $\mathrm{x}$ & $\mathrm{x}$ & $\mathrm{x}$ \\
\hline 27. Tricolpites phillipsii Stover $1973^{*}$ & & & & & $\mathrm{x}$ \\
\hline 28. Tricolpites reticulatus (Couper) Jarzen \& Dettmann 1989 & & & $\mathrm{x}$ & & $\mathrm{x}$ \\
\hline 29. Tricolporate A (cluster) & & & $\mathrm{x}$ & & \\
\hline 30. Tricolporate prolate (Apiaceae type) * & & & & & $\mathrm{x}$ \\
\hline 31. Ulmoideipites patagonicus Archangelsky 1973 & & $\mathrm{x}$ & $\mathrm{x}$ & & $x$ \\
\hline \multicolumn{6}{|l|}{ Algae } \\
\hline 1. Pediastrum boryanum (Turpin) Meneghini $1840^{*}$ & & $\mathrm{x}$ & & & \\
\hline 2. Zygnemataceae & & & $\mathrm{x}$ & & \\
\hline 3. Dinoflagellate cysts & & $\mathrm{x}$ & $\mathrm{x}$ & $\mathrm{x}$ & \\
\hline
\end{tabular}

$\mathrm{x}$-taxon present.

*Indicates first record in Salamanca Formation.

+Indicates the local section and stratigraphic level for each sample (see Fig. 9 and Table DR2 for reference [see footnote 1]). PL—Palacio de los Loros; DH—Dromedary Hill; CC-Cerro Colorado. 

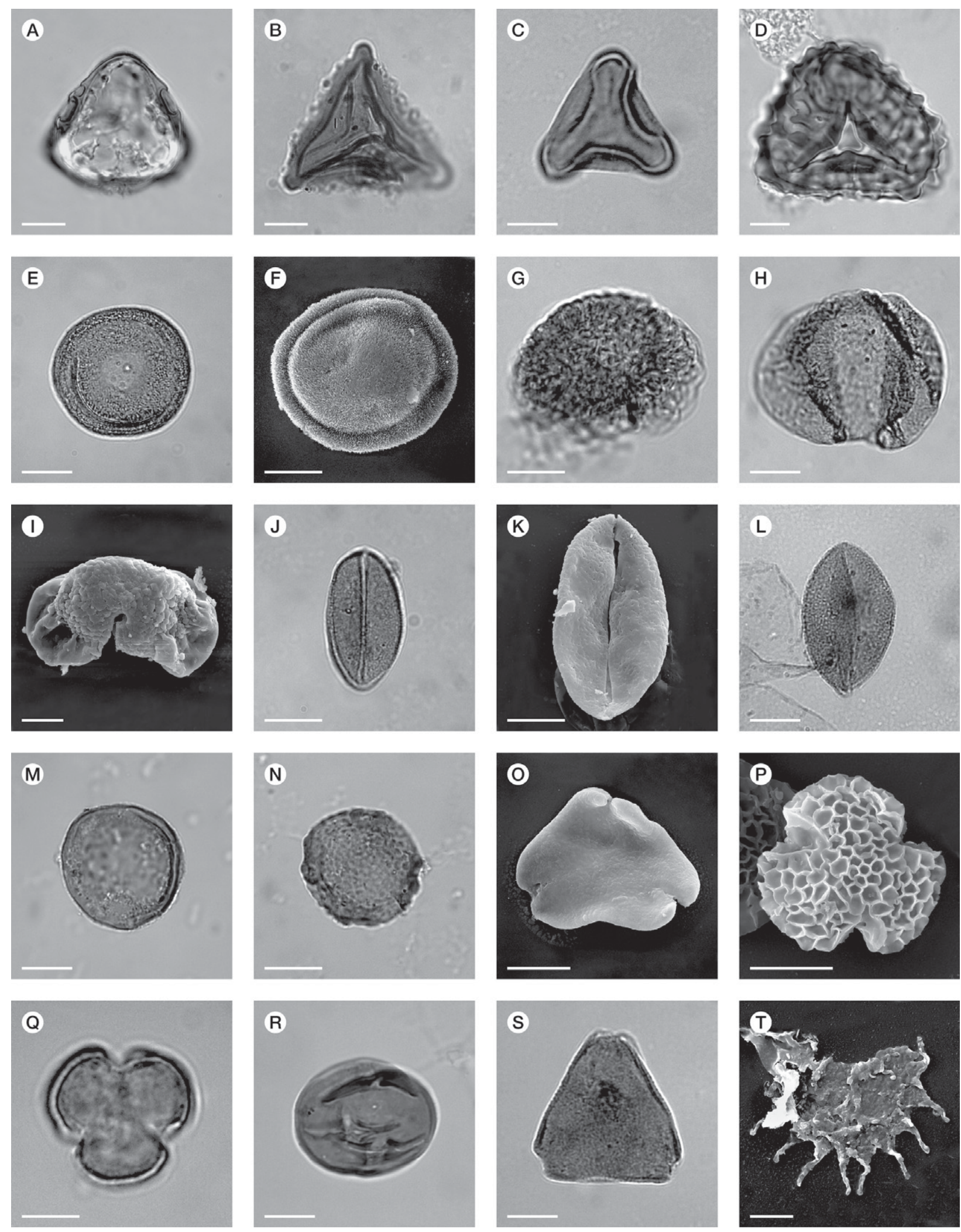

Figure 4. Microphotographs of selected terrestrial palynomorphs, Salamanca Formation. (A) Kuylisporites waterbolkii. (B) Clavifera triplex with scanning electron microscope (SEM). (C) Dictyophyllidites concavus. (D) Trilites parvalatus. (E-F) Classopollis Sp., F with SEM. (G) Dacrydiumites praecupressinoides. (H) Podocarpidites marwickii. (I) Podocarpidites rugulosus with SEM. (J-K) Arecipites minutiscabratus, K with SEM. (L) Liliacidites vermireticulatus. (M) Proxapertites sp. (N) Ulmoideipites patagonicus. (O) Peninsulapollis gillii with SEM. (P) Tricolpites anguloluminosus with SEM. (Q) Tricolpites communis. (R) Psilatricolporites Sp. (S) Proteacidites sp. (T) Pediastrum boryanum with SEM. Scale bars = 10 um. 
Figure $5 .{ }^{40} \mathrm{Ar} /{ }^{39} \mathrm{Ar}$ age spectrum (A) and inverse isochron (B) diagrams for sample LF1007, La Angostura Basalt (Fig. 1). The preferred age of $67.31 \pm 0.55 \mathrm{Ma}$ $( \pm 2 \sigma)$ is given by the inverse isochron shown in B. Ages were calculated relative to $28.201 \pm$ 0.046 Ma (Kuiper et al., 2008) for the Fish Canyon sanidine standard using decay constants of Min et al. (2000) and an ${ }^{40} \mathrm{Ar} /{ }^{36} \mathrm{Ar}$ value of $295.5 \pm 0.5$ for atmospheric Ar (Steiger and Jäger, 1977).
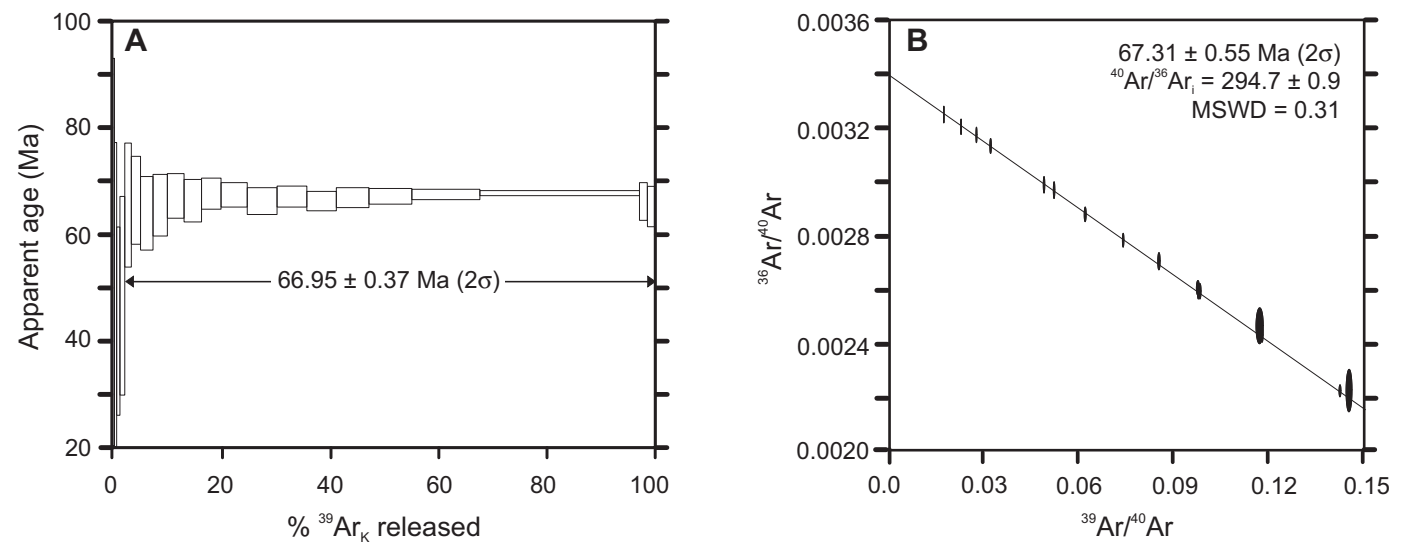

IRM analysis of samples from the red beds in the Peñas Coloradas Formation was not conducted, but high unblocking temperatures of the NRM in these samples indicated hematite was the dominant magnetic carrier in these samples.

Characteristic remanent directions were calculated using least squares analysis for samples where linear decay toward the origin was observed (Kirschvink, 1980; Figs. 7A-7C). However, several samples showed an initial decay followed by clustering of vector endpoints, and in these cases a Fisher mean was calculated to determine the characteristic direction of the sample (Fig. 7D). Characteristic directions were determined for three samples from each site, and a site mean was computed. The Watson (1956) test for randomness was then used to identify sites with significant clustering of sample directions (Table DR2). All results are reported in geographic coordinates, given that the beds are sub-horizontal and the small observed dips $\left(<6^{\circ}\right)$ could be depositional in nature. The mean direction of normal and inverted reverse polarity sites are within each other's $\alpha_{95}$ circles of confidence and pass the reversals test of Tauxe (1998), indicating that they are antipodal and that secondary NRM components have been removed from the samples (Fig. 8). A paleomagnetic pole with longitude/latitude of $36.5^{\circ}-84.5^{\circ}\left(\alpha_{95}=6.3^{\circ}\right)$ calculated from site virtual geomagnetic pole results from this study overlaps the $65 \mathrm{Ma}$ pole for South America $\left(13.7^{\circ} /-82.0^{\circ}, \alpha_{95}=3.6^{\circ}\right.$; Besse and Courtillot, 2002), further supporting the primary nature of the remanent magnetizations in these samples.

Site mean directions reveal four polarity intervals in the measured sections from Ormaechea and Palacio de los Loros (Fig. 9). The Dromedary Hill section in Ormaechea Park contains a reversed and a normal polarity interval in the Bajo Barreal Formation and a normal polarity interval in the Salamanca Formation that extends up through the BNI. The Cerro Colorado section in Ormaechea shows normal polarity for the upper Salamanca Formation and BNI with a reversal in the lower half of the Peñas Coloradas Formation, though the position of this reversal is not well constrained due to sparse sampling in this part of the section. A normal polarity interval is then observed, beginning in the base of the Las Flores Formation. Correlative sections at Palacio de los Loros (a and b, see Fig. 9) show a very similar reversal pattern, with normal polarity for the uppermost Bajo Barreal Formation and the full Salamanca Formation (up through the BNI) followed by a reversal in the lower Peñas Coloradas Formation (Fig. 9). Results from the Las Flores area are also consistent with the Ormaechea record in having a normal polarity site in the upper Bajo Barreal Formation (just below the dated basalt) and two normal polarity sites in the lower Peñas Coloradas Formation, where a macrofloral site is located (Table DR2). Results from two sites in the Salamanca Formation from the Rancho Grande section, containing another paleobotanical locality, are indicative of normal polarity, and thus consistent with results from Ormaechea and Palacio de los Loros, but these do not pass the Watson test for randomness and so are less reliable.

\section{DISCUSSION}

\section{Chronostratigraphy}

The new magnetostratigraphic, biostratigraphic, and geochronological data reported here can be combined with other published information within a sequence stratigraphic framework to correlate the Bajo Barreal-Salamanca-Río Chico succession in the study area to the geomagnetic polarity time scale (GPTS; Gradstein et al., 2012; Fig. 10). The existence of a lithologic unconformity at the contact between the Bajo Barreal Formation and the overlying Salamanca Formation, as well as the lack of evidence for a reversed polarity interval that could correspond to Chron 29r (which spans the K-Pg boundary), makes it almost certain that the normal polarity associated with those two units represents different chrons separated by a hiatus. The Bajo Barreal Formation is poorly constrained in time but is generally thought to be Cenomanian-Turonian in age based on ${ }^{40} \mathrm{Ar} /{ }^{39} \mathrm{Ar}$ ages reported from it and the overlying Laguna Palacios Formation (Bridge et al., 2000), as well as its dinosaur fauna (Lamanna et al., 2002; Casal et al., 2009; Navarrete et al., 2011). Our results indicate a reverse-to-normal polarity transition in the uppermost Bajo Barreal in the study area. Because the Cretaceous Normal Superchron (C34n) lasts from the Aptian to the Santonian-Campanian boundary and does not contain any known reversals within it that are younger than the Albian (ca. $100 \mathrm{Ma}$ ), the reversal in our section of the Bajo Barreal must be Campanian or younger in age, suggesting that the upper Bajo Barreal Formation in this area is younger than generally thought. This is supported by nearby dinosaur fossils from the upper Bajo Barreal that suggest a Campanian?Maastrichtian age (Casal et al., 2007; Ibiricu et al., 2010). Given these various age constraints, we correlate the polarity reversal in the upper Bajo Barreal Formation to the C33r$\mathrm{C} 33 \mathrm{n}$ reversal but acknowledge that it could be a younger, Campanian or Maastrichtian reversal.

The early Danian foraminifera, calcareous nannofossils, and dinoflagellates reported here from the base of the Salamanca Formation indicate that the normal polarity interval in the lower part of the Salamanca Formation is Chron C29n (65.69-64.96 Ma). The U-Pb age of 61.98 Ma from the overlying Peñas Coloradas Formation indicates that its reversed polarity zone (which contains the dated tuffs) is most likely Chron C26r (62.22-59.24 Ma; Fig. 9) with the 

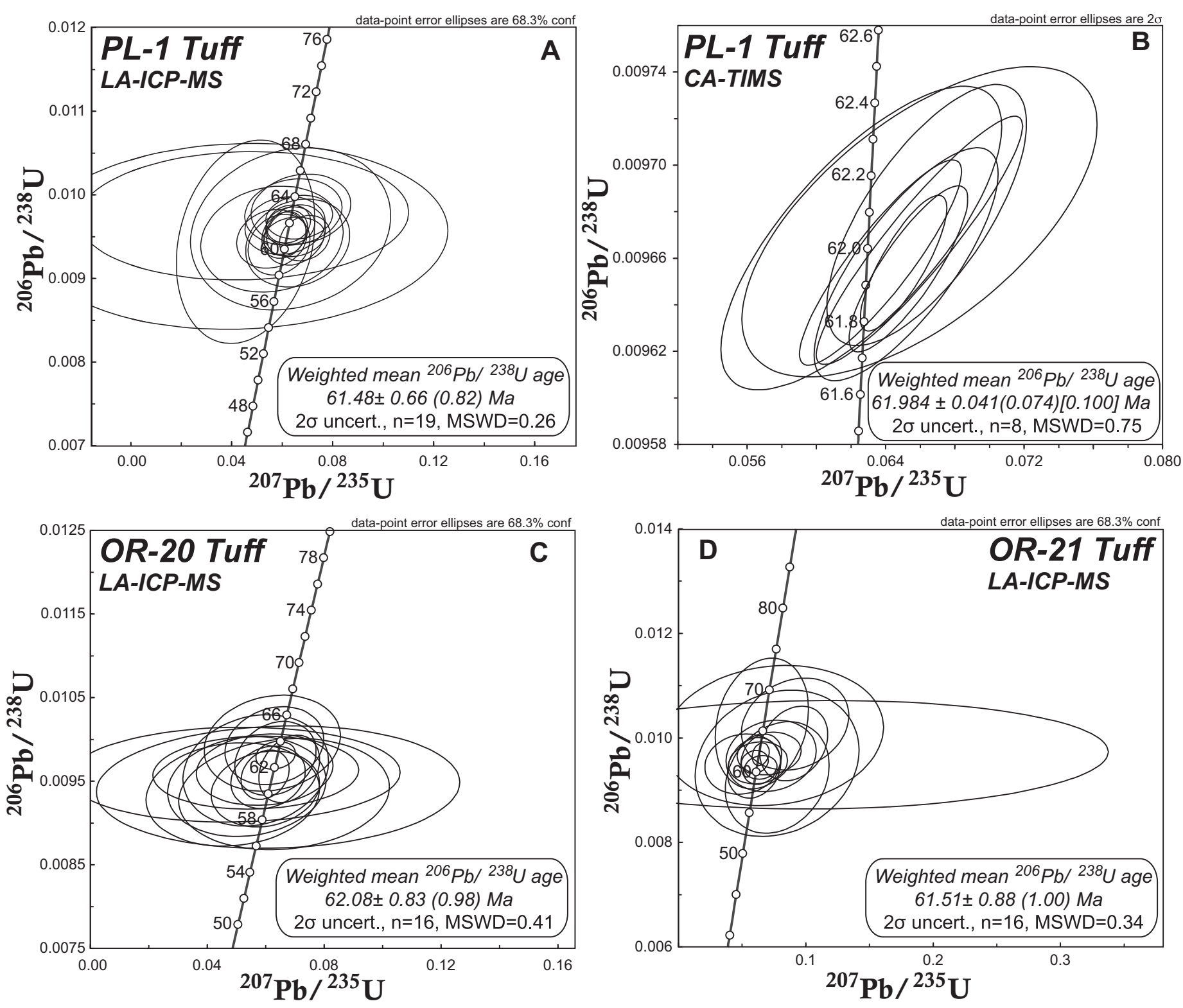

Figure 6. U-Pb concordia diagrams for the volcanic horizons (tuffs) analyzed in this study from the Peñas Coloradas Formation. Results obtained by laser ablation-inductively coupled plasma-mass spectrometry (LA-ICP-MS) analysis are shown for tuffs PL-1 (A), OR-20 (C), and OR-21 (D), whereas results obtained by chemical abrasion-thermal ionization mass spectrometry (CA-TIMS) are shown for tuff PL-1 (B). Single-zircon grains analyzed using TIMS from the PL-1 tuff sample, collected from the Palacio de los Loros locality, were selected on the basis of their LA-ICP-MS ages. OR-20 and OR-21 tuff samples were collected from Ormaechea Petrified Park. Errors are expressed in the form $\pm \mathrm{X}(\mathrm{Y})[\mathrm{Z}]$, where $\mathrm{X}$ is solely analytical uncertainty, $\mathrm{Y}$ is the combined analytical and tracer uncertainty, and $\mathrm{Z}$ is the combined analytical, tracer, and ${ }^{238} \mathrm{U}$ decay constant uncertainty. See text and Table DR1 ${ }^{1}$ for details.

normal polarity interval at the base of the Peñas Coloradas Formation in all likelihood correlating to $\mathrm{C} 27 \mathrm{n}$ (62.52-62.22 Ma) given the general stratigraphic continuity within this formation.

The intervening strata of the upper Salamanca Formation and BNI are all normal polarity and lack additional chronologic constraints, meaning that they belong to some combination of C29n, C28n, and/or C27n and that at least one, and probably more, significant unconformities must be present that erased two corresponding reversed polarity intervals $(\mathrm{C} 28 \mathrm{r}$ and $\mathrm{C} 27 \mathrm{r}$ ). The most likely positions for large unconformities are within the upper Salamanca Formation (between the Fragmentosa and the Banco Verde beds) and between the BNI and the overlying Peñas Coloradas Formation. These two erosional surfaces have been clearly identified in coastal successions (Legarreta et al., 1990; Legarreta and Uliana, 1994; Bond et al., 1995), and our own observations suggest they are developed in the study area as well (Comer, 2011).

The stratigraphic position of unconformities and intervening sedimentary systems tracts can be combined with the updated chronologic data and a global eustatic sea level curve to develop a sequence stratigraphic interpretation for the Salamanca Formation that provides an internally consistent chronostratigraphy of early Paleocene deposition in the study area (Comer, 2011; 

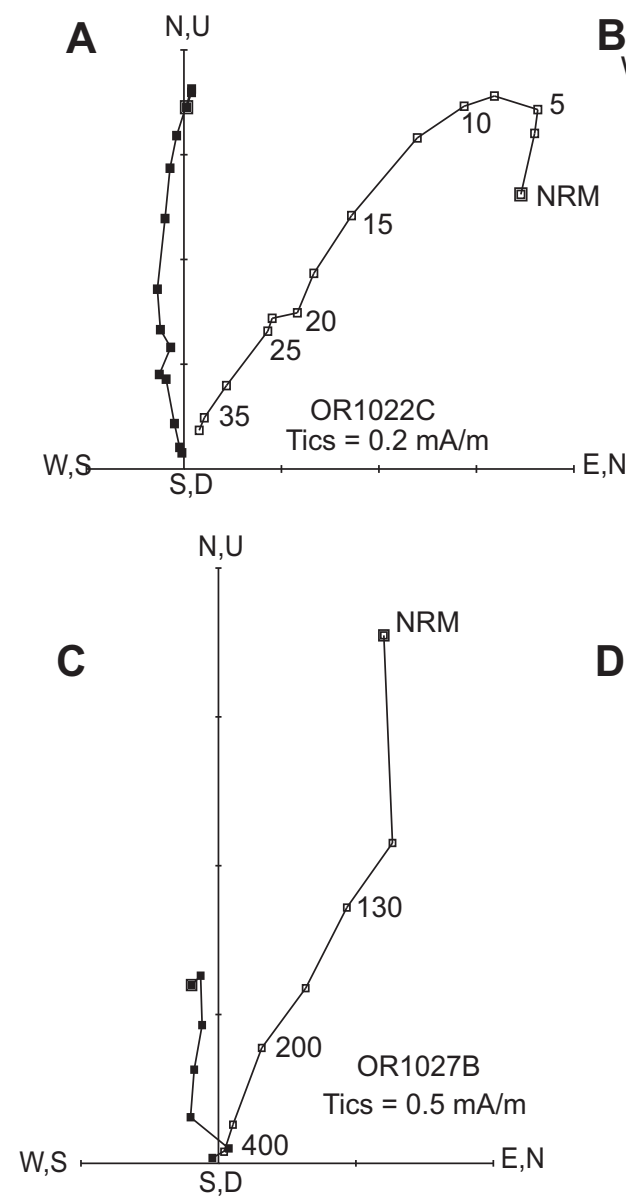
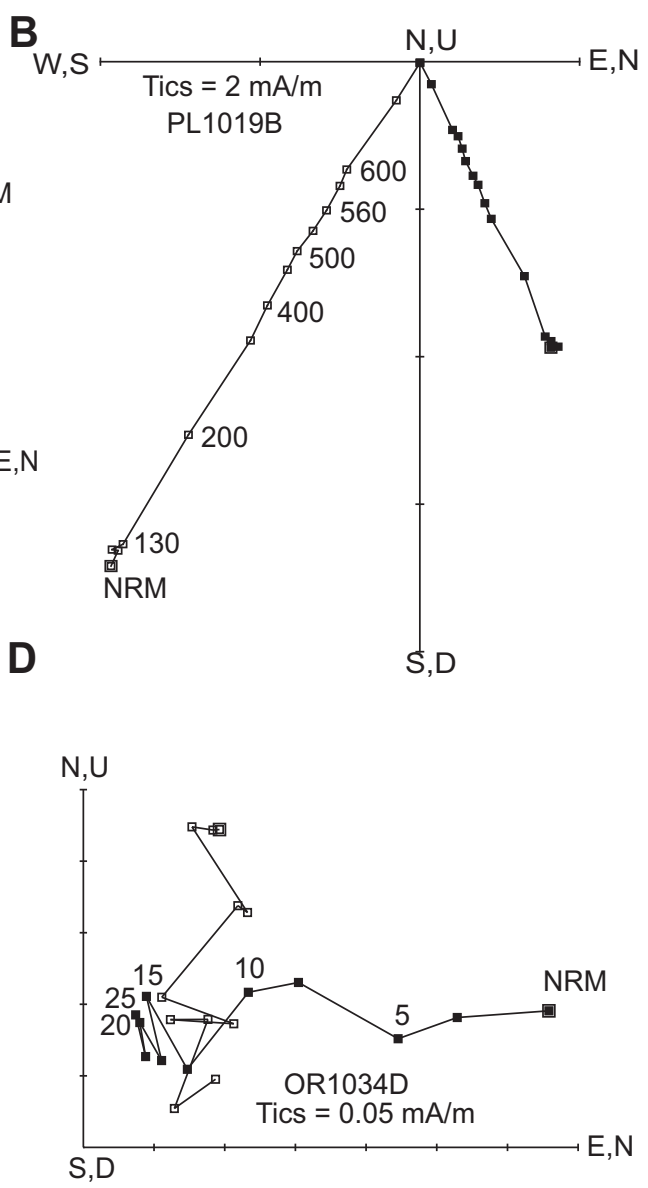

Figure 7. Representative vector end point diagrams of paleomagnetic samples from the San Jorge Basin. Open (filled) symbols represent points in the vertical (horizontal) plane. (A-C) Samples whose characteristic remanent directions were calculated using least squares analysis because demagnetization directions exhibit linear decay toward the origin. (D) Sample showing an initial decay followed by clustering of vector endpoints. The characteristic remanent directions for samples like that shown in D were calculated using a Fisher mean. See Table DR2 ${ }^{1}$ for sample information. N-north, W-west, S-south, E-east, Uup, D-down, NRM-natural remanent magnetization, numbers next to data points in $B$ and $\mathrm{C}$ are temperatures (degrees $\mathrm{C}$ ), numbers next to data points in $\mathrm{A}$ and $\mathrm{D}$ are alternating magnetic fields (millitesla). Numbers parallel to $\mathrm{x}$-axes are sample numbers.

Fig. 10). It is assumed in this analysis that the San Jorge Basin was slowly but continuously subsiding during this time. The unconformity between the Bajo Barreal and the Salamanca Formation was likely associated with non-deposition and erosion during the Late Cretaceous when eustatic sea level was moderately low (Kominz et al., 2008; see sequence boundary SB-1 in Fig. 10). Salamanca deposition began during Chron C29n in the study area, during the early Danian marine transgression, but likely initiated earlier in the east, as would be expected for a transgressive systems tract (Fig. 10). The sequence boundary between the Fragmentosa and Banco Verde facies (SB-2 in Fig. 10) likely formed during a mid-Danian fall of eustatic sea level
(Kominz et al., 2008) that resulted in a eustatic lowstand in Chron 28n. The combination of constant eustatic sea level at lowstand and basin that allowed a lowstand systems tract of the Banco Verde to form. The subsequent eustatic sea level rise and highstand created the overlying transgressive (uppermost Banco Verde) and highstand (BNI beds) systems tracts of the upper Salamanca Formation. The BNI represents a prograding coastal swamp deposit that has traditionally been associated with shoreline regression (Legarreta and Uliana, 1994; Bellosi et al., 2000; Bond et al., 1995; Matheos et al., 2001, 2005; Raigemborn et al., 2010; Comer, 2011). This is consistent with a highstand systems subsidence created net accommodation space

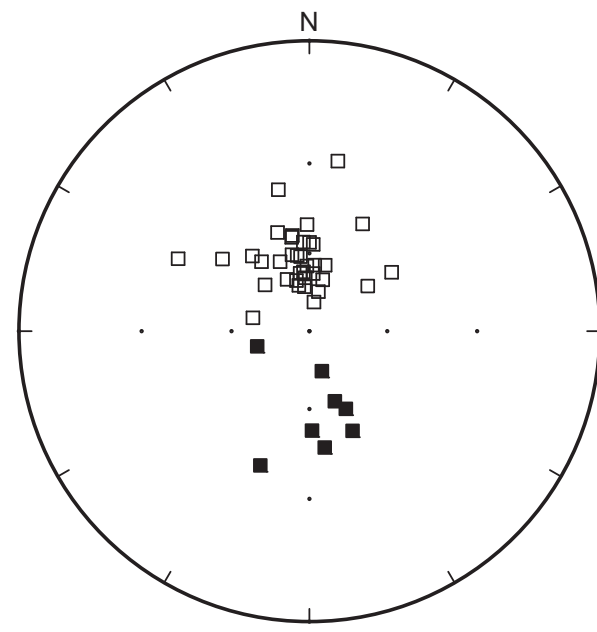

Figure 8. Equal area projection of site mean directions that satisfied the Watson test for randomness (Table DR2 ${ }^{1}$ ). Open (closed) symbols are on the upper (lower) hemisphere. Directions are shown in geographic coordinates because dips are not greater than $6^{\circ}$ and may be depositional in nature.

tract interpretation in which sediment accommodation space is created slowly and the coastal deposits prograde. We see no evidence that this is a falling stage systems tract created by a forced regression. A third eustatic sea level fall created a third sequence boundary (SB-3) that separates the Banco Negro Inferior from the superjacent Peñas Coloradas Formation. The onset of Peñas Coloradas deposition in Chron C27n represents the end of marine deposition in the San Jorge Basin until at least the Oligocene (Legarreta and Uliana, 1994). The sequence stratigraphic interpretation shown here represents the best match to the updated chronological data and to existing understanding of Late Cretaceous-Paleocene eustatic sea level changes, but other interpretations are also possible. To fully test these alternatives, a more precise age estimate for the upper Salamanca Formation and BNI will need to be determined via further geochronological, paleomagnetic, and biostratigraphic analyses in other areas of the basin (especially along the coast).

\section{Paleobiological Implications}

Iglesias et al. (2007) estimated the age of the fossil floras from Palacio de los Loros to be ca. 61.7 Ma, primarily based on the occurrences of Danian Zone P1C foraminifera in coastal sections of the Salamanca Formation (Bertels, 1975). Zone P1C spans part of C28n and all of $\mathrm{C} 27 \mathrm{r}$, ending near the Danian-Selandian boundary (ca. 61.7 Ma in the 2004 geologic time scale [GTS] used at the time), which, in the absence of 


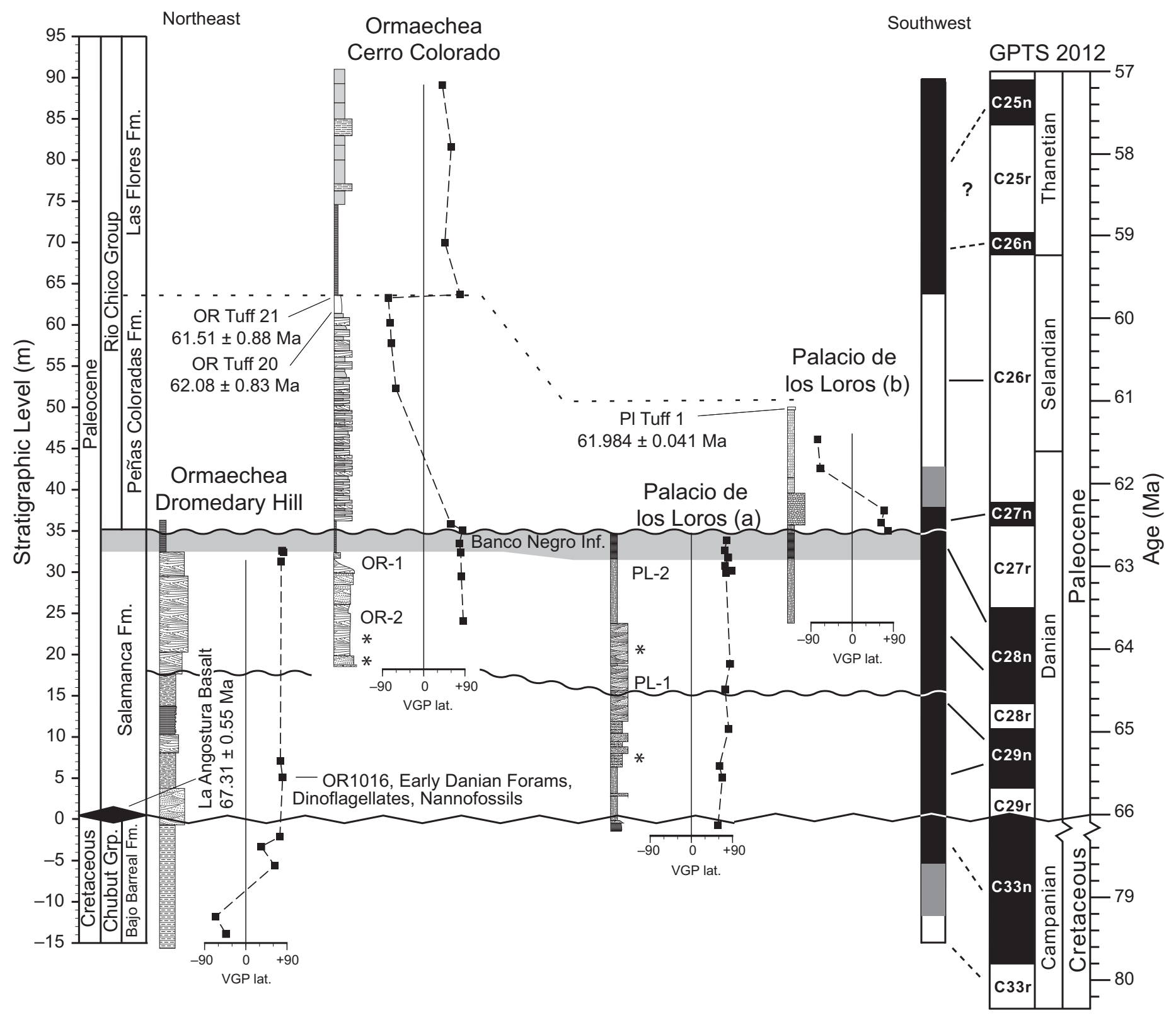

Figure 9. Summary of new chronostratigraphic information for the Salamanca Formation (including Banco Negro Inferior) and lower Río Chico Group for the sections studied here from near Sarmiento, Argentina (Patagonia; Fig. 1). Lithostratigraphic information is plotted alongside virtual geomagnetic pole latitude (VGP lat.; $+90^{\circ}$ to $-90^{\circ}$ ) with relevant biostratigraphic and radioisotopic information tied to local sections. Isotopic ages are shown with errors of $\pm \mathbf{2 \sigma}$ for analytical uncertainty only (see text for details). Stratigraphic positions of important compression fossil plant localities are shown next to lithological logs (OR-1, OR-2, PL-1, PL-2; Iglesias et al., 2007). Stratigraphic levels with abundant fossilized tree stumps and logs are shown with an asterisk. The composite local magnetic polarity pattern is plotted to the right alongside the preferred potential correlation to the geomagnetic polarity time scale (GPTS; Gradstein et al., 2012); solid lines are well-established correlations, and dashed lines are uncertain correlations. Major unconformities are marked with wavy lines (see text for discussion; black represents normal polarity, white represents reversed polarity, and gray represents uncertain polarity).

other constraints, Iglesias et al. took as a conservative age estimate for the floras. Our new age constraints, and especially the normal polarity results for their stratigraphic interval, indicate that the fossil plant compression assemblages from Palacio de los Loros are probably entirely from Chron C28n (64.67-63.49 Ma in the 2012
GTS; Gradstein et al., 2012), which means these comparatively high-diversity floras are $\sim 2-3$ million years older than previously thought and indicate an even faster post-K-Pg recovery. In addition, our results indicate a likely age within $\mathrm{C} 28 \mathrm{n}$ for the compression flora from an isolated outcrop at Rancho Grande (Fig. 1;
Iglesias, 2007), correlative with the floras at Palacio de los Loros and Ormaechea, and an age within C27n (late Danian) for the fossil flora in the lower Peñas Coloradas Formation in the Las Flores section (Fig. 1; Iglesias, 2007). Despite being $\sim 1.5$ m.y. younger and coming from a very different, fluvio-volcanic deposi- 


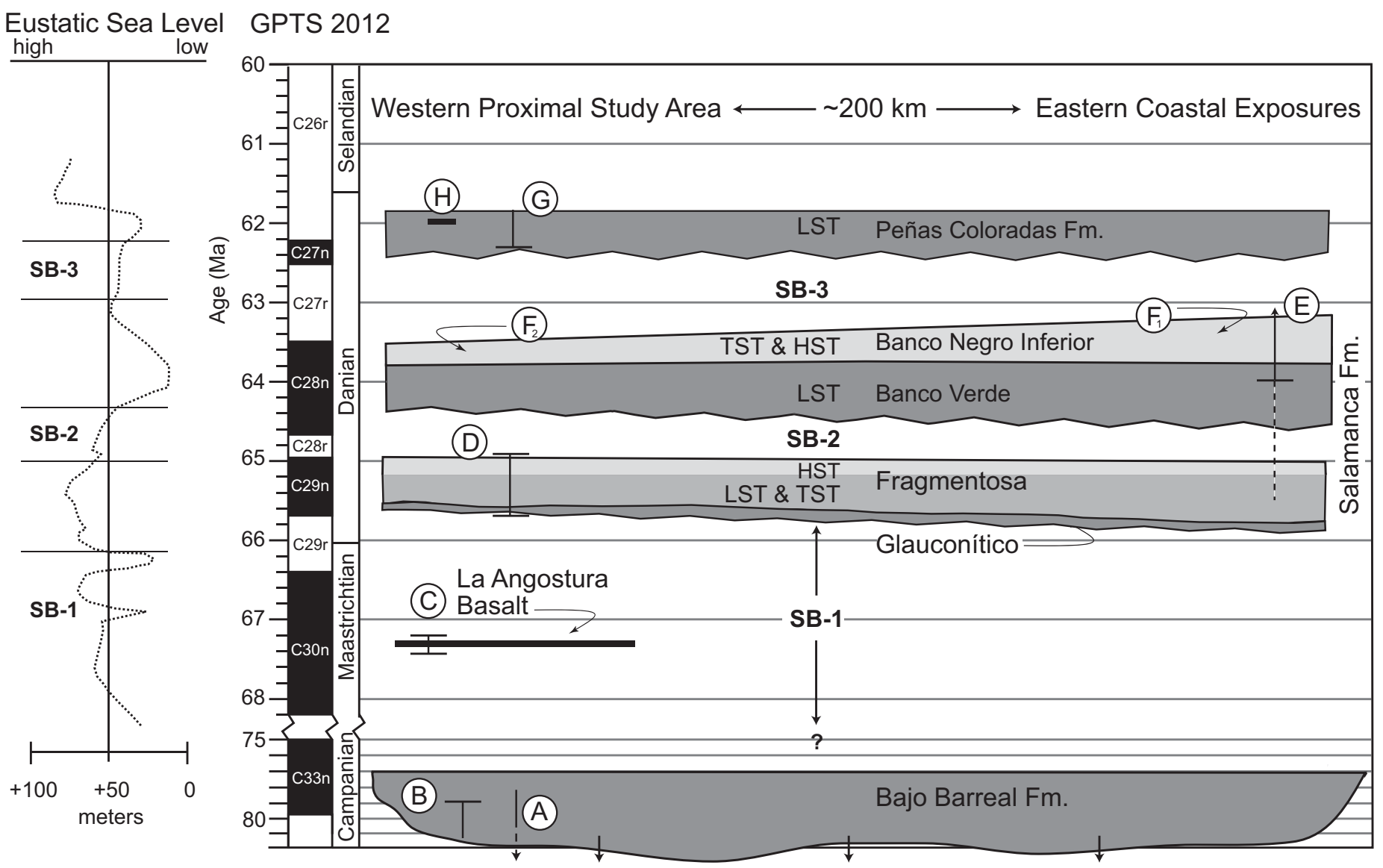

Figure 10. Wheeler diagram of stratigraphic events in the study area during the Late Cretaceous through early Paleocene. (A) Radiometric ages and dinosaurs from Bajo Barreal Formation suggest a Cenomanian-Turonian age (Bridge et al., 2000; Lamanna et al., 2002; Casal et al., 2009; Navarrete et al., 2011). (B) However, a reverse to normal polarity reversal (this study) indicates that the upper part must range at least into the Campanian given that the Cretaceous Normal Superchron lasts from the Aptian to the Santonian-Campanian boundary. (C) The La Angostura basalt that lies between the Bajo Barreal and Salamanca Formations is dated to $67.31 \pm 0.55 \mathrm{Ma}$ (this study). (D) Planktonic foraminifera, dinoflagellates, calcareous nannofossils, and paleomagnetic data place the base of the Salamanca in the study area in early Danian normal polarity Chron C29n (this study). (E) Planktonic foraminifera from coastal Salamanca exposures are mid- to upper Danian Zone P1c (Bertels, 1975; Méndez, 1966; dashed line indicates uncertain stratigraphic position of those samples). ( $\left.F_{1}-F_{2}\right)$ The Banco Negro Inferior is reversed polarity at the coast $\left(F_{1}\right)$ (but may straddle a reversal there as indicated; see Somoza et al., 1995) whereas it is normal polarity in the study area $\left(F_{2}\right)$ (this study). (G) A normal-to-reverse polarity reversal occurs at the Ormaechea and Palacio de los Loros localities in the lower Peñas Coloradas Formation (this study). (H) Zircons from a tuff in the upper Peñas Coloradas Formation are dated to $61.98 \pm 0.041(0.074)[0.100]$ Ma (this study; see text for explanation of uncertainty). Eustatic sea level curve is from Kominz et al. (2008). Salamanca facies names are after Bond et al. (1995). GPTS—geomagnetic polarity time scale. LST-lowstand systems tract, TST - transgressive systems tract, HST—highstand systems tract, SB-1—sequence boundary 1, SB-2—sequence boundary 2, and SB-3 sequence boundary 3 .

tional environment, the Las Flores flora has very similar composition to those from Palacio de los Loros and Ormaechea (Iglesias, 2007), showing continuity through time of this coastal forest floral association.

The relatively high plant diversity during the early Paleocene observed here is consistent with recent palynological results from the Lefipán Formation $(\sim 350 \mathrm{~km}$ north of the study area), where a short-term microfloral turnover and decline in species richness at the K-Pg boundary was rapidly followed by a rebound in diversity during the Danian to levels similar to the Maastrichtian (Barreda et al., 2012). The Salamanca macrofloral diversity pattern that is implied by the new age constraints reported here adds to the growing evidence for lower extinction at, and more rapid Southern Hemisphere biotic diversification after, the K-Pg extinction compared to the Northern Hemisphere (Case and Woodburne, 1986; Wolfe, 1987; Askin, 1988; Vajda and McLoughlin, 2007; Jiang et al., 2010; Wilf et al., 2013). Whether this trend is associated with greater distances from the Chicxu- lub impact site, differences in biogeographic dynamics such that Southern Hemisphere continents acted as refugia, or something else, remains unknown.

Our new chronostratigraphic interpretation for the Salamanca Formation also provides important temporal constraints on the Banco Negro Inferior and its fossil assemblages. Marshall et al. (1981) analyzed the paleomagnetism of the BNI along the coast (Punta Peligro and Cerro Redondo) and found it to be characterized by reversed polarity. The BNI is shown here to 
be normal polarity in the Sarmiento area, which means that it is definitely a time-transgressive unit (see also Somoza et al., 1995). Our new chronologic constraints and sequence stratigraphic interpretation suggest that the BNI is progradational from west to east and correlates to the top of Chron C28n near Sarmiento and to the base of Chron C27r (63.49 Ma) along the coast (Fig. 10). This interpretation makes the BNI, and associated Peligran SALMA, significantly older than the early Selandian (ca. 62-60 Ma) age that it was previously assigned (Marshall et al., 1981; Somoza et al., 1995; Bonaparte et al., 1993; Gelfo et al., 2009). The Peligran SALMA is then correlative with the early Torrejonian North American Land Mammal Age (NALMA) and Shanghuan Asian Land Mammal Age (ALMA; Clyde et al., 2010). These results also imply that the Peligran SALMA is closer in age to (or possibly older than) the Tiupampan SALMA. The Tiupampan SALMA has most recently been referred to as earliest Paleocene and correlated with the Puercan NALMA, but is based entirely on a mammal fauna from the poorly dated Santa Lucía Formation in Bolivia that has been variously attributed to the Upper Cretaceous through Selandian (see discussion in Gelfo et al., 2009).

Our results from the western San Jorge Basin also have implications for the age of important fossiliferous units of the Río Chico Group and their associated SALMAs. Based mostly on fossil localities near the coast, Simpson (1935b) first divided Río Chico stratigraphy into three mammalian faunal zones (Carodnia, Kibenikhoria, and Ernestokokenia), which correlate with the three lithological units exposed there (Peñas Coloradas, Las Flores, and Koluel-Kaike Formations, respectively, as near Sarmiento). The Kibenikhoria zone of the Las Flores Formation is often referred to the Itaboraian SALMA, and the Ernestokokenia zone of the Koluel-Kaike Formation forms the basis of the Riochican SALMA (Bond et al., 1995). The "Carodnia" zone is based on very few taxa found in Peñas Coloradas exposures near the coast (e.g., Carodnia feruglioi and Notoetayoa gargantuai) and thus has not been elevated to Land Mammal Age status, but it is still thought to represent a distinct period of South American faunal evolution. The possible correlation of the "Carodnia" zone assemblage (as well as the Kibenikhoria zone as mentioned) to the poorly dated fissure-fill assemblages at Itaboraí in Brazil is often discussed (Simpson, 1935a, 1935b; de Paula Couto, 1952; Bond et al., 1995; Marshall et al., 1997; Gelfo et al., 2009). Our new $\mathrm{U}-\mathrm{Pb}$ isotopic date of $61.98 \mathrm{Ma}$ from the upper Peñas Coloradas Formation near Sarmiento, as well as its dominantly reversed magnetic polar- ity (as it is near the coast; Marshall et al., 1981), indicates that it falls mostly within C26r (62.22$59.24 \mathrm{Ma}$ ) and is thus latest Danian in age. This makes the "Carodnia" zone (at ca. $62 \mathrm{Ma}$ ) significantly older than generally thought (e.g., Thanetian, ca. 58-56 Ma; Gelfo et al., 2009) and equivalent to, or at least overlapping with, the early Tiffanian NALMA and Nongshanian ALMA (Clyde et al., 2010). Given the possibility for diachroneity within Río Chico facies, direct testing of this correlation will require geochronological results from the coastal sections of the Peñas Coloradas Formation that actually produced the "Carodnia" zone fossils.

The original Kibenikhoria zone fossils described by Simpson (1935a, 1935b) were recovered from Río Chico facies at Cañadon Hondo, which lies about halfway between Sarmiento and the modern coast. Legarreta and Uliana (1994) and Bond et al. (1995), who recognized distinct, sequence-bounded litho-biostratigraphic packages within the early Paleogene stratigraphy of the San Jorge Basin, associated this fauna with the Las Flores Formation. Additional vertebrate specimens from the Las Flores Formation are now known from east of Sarmiento city at the eastern tip of Gran Barranca (Cione et al., 2011) and along the coast near Comodoro Rivadavia (Krause and Piña, 2012). Our results indicate that the bottom part of the Las Flores Formation south of Sarmiento is characterized by normal polarity, which must represent Chron C26n or younger based on the new geochronological results for the underlying Peñas Coloradas Formation presented here. Currently, the only reliable age constraint from above the Las Flores Formation comes from the Sarmiento Formation, which lies above the Koluel-Kaike Formation and is correlated to Chron C19r at its base (42.30-41.39 Ma; Ré et al., 2010; Dunn et al., 2012). This means that the Las Flores Kibenikhoria fauna (likely equivalent to, or overlapping with, the Itaboraian SALMA) and the Riochican SALMA could theoretically be anywhere from late Paleocene to middle Eocene in age. Additional geochronological studies of the Las Flores and Koluel-Kaike Formations are clearly needed to better resolve the age of these units and their associated faunas. This is particularly important given the likelihood of large unconformities within this interval and the importance of determining the position of the Paleocene-Eocene boundary in the San Jorge Basin stratigraphy.

\section{CONCLUSIONS}

New biostratigraphic, radioisotopic, and paleomagnetic data from the fossiliferous Bajo Barreal Formation, Salamanca Formation, and overlying Río Chico Group in the Sarmiento area of Chubut, Argentina (central Patagonia), are placed in a sequence stratigraphic framework to develop a revised chronostratigraphy for the Late Cretaceous-early Paleogene deposits of the San Jorge Basin. Implications of this new chronostratigraphy are that (1) the Bajo Barreal Formation in this area ranges up to at least the Campanian (i.e., <83.6 Ma), (2) the Salamanca Formation (including the BNI) in the study area ranges from early to middle Danian (early Paleocene; ca. 65.7-63.5 Ma), and (3) the Peñas Coloradas Formation is latest Danian in age (ca. 62.5-61.6 Ma). Previously reported diverse fossil plant assemblages from the same sections studied here are from Chron C28n (64.67-63.49 Ma) and thus $\sim 2$ million years older than previously thought, supporting recent results suggesting a more rapid Southern Hemisphere biotic recovery from the K-Pg extinction compared to the Northern Hemisphere. Important fossil vertebrate faunas from the Banco Negro Inferior (Peligran SALMA) and Peñas Coloradas Formation ("Carodnia" zone) from areas farther to the east are also interpreted to be considerably older than generally acknowledged, correlating to the early Torrejonian NALMA/Shanghuan ALMA and the early Tiffanian NALMA/Nongshanian ALMA respectively.

\section{ACKNOWLEDGMENTS}

Thanks to N.R. Cúneo, K. Johnson, and P. Puerta for discussion and help with field logistics; N.L.D Welters, J.v. Tongeren, C. Jaramillo, and Paleoflora Ltd. for palynological slide preparation; P. Balcells for the preparation of the pollen and spores figure; J.P. Pérez Panera for discussion of nannofosils; Secretaría de Cultura and Secretaría de Turismo y Áreas Protegidas from Chubut Province and Sarmiento City for land permits; and H. Visser, C. Salazar-Bochatey, Martínez families, and A. Balercia for land access. This research was funded by National Science Foundation (NSF) grant DEB-0919071 to P.W., A.I., and R.L.S., and by the European Research Council under the European Community's Seventh Framework Program through Starting Grant 259627 to A.S. P.K.B. thanks the LPP foundation and H.B. the Netherlands Organization for Scientific Research (NWO grant 86610110). The Arizona Laserchron center is supported by NSF grants EAR-0443387 and EAR-0732436.

\section{REFERENCES CITED}

Ameghino, F., 1906, Les formations sédimentaires du Crétacé et du Tertiare de Patagonie, avec un paralèlle entre leurs faunes mammalogiques et celles de l'ancien continent: Anales del Museo Nacional de Historia Natural, v. 15 , p. $1-568$.

Andreis, R.R., 1977, Geología del área de Cañadón Hondo, Dpto. Escalante, Provincia de Chubut, República Argentina: Obra del Centenario del Museo de La Plata, v. 4 , p. $77-102$

Andreis, R.R., Mazzoni, M., and Spalletti, L.A., 1975, Estudio estratigráfico y paleoambiental de las sedimentitas Terciarias entre Pico Salamanca y Bahía Bustamante, Provincia de Chubut, República Argentina: Revista de la Asociación Geológica Argentina, v. 30, p. 85-103. 
Archangelsky, S., 1973, Palinología del Paleoceno de Chubut. I. Descripciones sistemáticas: Ameghiniana, v. 10 , p. 339-399.

Archangelsky, S., 1976, Palinología del Paleoceno de Chubut. II. Diagramas polínicos: Ameghiniana, v. 13, p. $43-55$.

Archangelsky, S., and Romero, E.J., 1974, Polen de gimnospermas (coníferas) del Cretácico superior y Paleoceno de Patagonia: Ameghiniana, v. 11, p. 217-236.

Archangelsky, S., and Zamaloa, M.C., 1986, Nuevas descripciones palinológicas de las formaciones Salamanca y Bororó, Paleoceno de Chubut (República Argentina): Ameghiniana, v. 23, p. 35-46.

Askin, R.A., 1988, The palynological record across the Cretaceous/Tertiary transition on Seymour Island, Antarctica, in Feldmann, R.M., and Woodburne, M.O., eds., Geology and Paleontology of Seymour Island Antarctic Peninsula: Geological Society of America Memoir 169, p. 155-162, doi:10.1130/MEM169-p155.

Barcat, C., Cortiñas, J.S., Nevistic, V.A., Zuchi, H.E., Chebli, G.A., and Spalletti, L.A., 1989, Cuenca Golfo San Jorge, in Chebli, G.A., and Spalletti, L.A., eds., Cuencas Sedimentarias Argentinas, Universidad Nacional de Tucumán, Instituto Superior de Correlación Geológica: Serie de Correlación Geológica, v. 6, p. 319-345.

Barreda, V.D., Cúneo, N.R., Wilf, P., Currano, E.D., Scasso, R.A., and Brinkhuis, H., 2012, Cretaceous/Paleogene floral turnover in Patagonia: Drop in diversity, low extinction, and a Classopollis spike: PLoS ONE, v. 7, e52455, doi:10.1371/journal.pone.0052455.

Batten, D.J., 1996. Colonial Chlorococcales, in Jansonius, J., and McGregor, D.C., eds., Palynology: Principles and Applications: Dallas, American Association of Stratigraphic Palynologists Foundation, p. 191-203.

Bellosi, E., Palamarczuk, S., Barreda, V., Sanagua, J., Jalfin, G., and Herbst, R., 2000, Litofacies y palinologia del contacto Grupo Chubut-Formacion Salamanca en el oeste de la Cuenca Golfo San Jorge, Argentina: Ameghiniana 37, no. 4, Suppl., p. 45-46.

Berry, E.W., 1937, A Paleocene flora from Patagonia: Johns Hopkins University: Studies in Geology, v. 12, p. 33-50.

Bertels, A., 1975, Bioestratigrafía del Paleógeno en la República Argentina: Revista Española de Micropaleontología, v. 7, p. 429-450.

Besse, J., and Courtillot, V., 2002, Apparent and true polar wander and the geometry of the geomagnetic field over the last 200 Myr: Journal of Geophysical Research, v. 107, 2300, doi:10.1029/2000JB000050.

Bona, P., 2007, Una nueva especie de Eocaiman Simpson (Crocodylia, Alligatoridae) del Paleoceno Inferior de Patagonia: Ameghiniana, v. 44, p. 435-445.

Bona, P., and de la Fuente, M.S., 2005, Phylogenetic and paleobiogeographic implications of Yaminuechelys maior (Staesche, 1929) new comb., a large long-necked chelid turtle from the early Paleocene of Patagonia, Argentina: Journal of Vertebrate Paleontology, v. 25, p. 569-582, doi:10.1671/0272-4634(2005)025[0569: PAPIOY]2.0.CO;2.

Bonaparte, J.F., and Morales, J., 1997, Un primitivo Notonychopidae (Litopterna) del Paleoceno inferior de Punta Peligro, Chubut, Argentina: Estudios Geológicos, v. 53 , p. $263-274$.

Bonaparte, J.F., Van Valen, L.M., and Kramartz, A., 1993, La fauna local de Punta Peligro, Paleoceno inferior, de la provincia del Chubut, Patagonia, Argentina: Evolutionary Monographs, v. 14, p. 1-61.

Bond, M., Carlini, A., Goin, F.J., Legarreta, L., Ortiz-Jaureguizar, E., Pascual, R., and Uliana, M.A., 1995, Episodes in South American land mammal evolution and sedimentation: Testing their apparent concurrence in a Paleocene succession from central Patagonia: Actas VI Congreso Argentino de Paleontología y Bioestratigrafía, Trelew, Argentina, p. 47-58.

Bown, P., 2005, Selective calcareous nannoplankton survivorship at the Cretaceous-Tertiary boundary: Geology, v. 33, p. 653-656, doi:10.1130/G21566.1.

Bown, P.R., and Young, J.R., 1998, Techniques, in Bown, P.R., ed., Calcareous Nannofossil Biostratigraphy: Boston, Kluwer Academic, p. 16-28.

Brea, M., Matheos, S., Zamuner, A., and Ganuza, D., 2005, Análisis de los anillos de crecimiento del bosque fósil de Víctor Szlápelis, Terciario inferior del Chubut, Argentina: Ameghiniana, v. 42, p. 407-418.

Brea, M., Zamuner, A.B., Matheos, S.D., Iglesias, A. and Zucol, A.F., 2008, Fossil wood of the Mimosoideae from the early Paleocene of Patagonia, Argentina: Alcheringa, v. 32, p. 427-441, doi:10.1080 /03115510802417695

Brenac, P., and Richards, K., 1996, Pediastrum as a guide fossil in sequence stratigraphy, in Proceedings, 9th International Palynological Congress: Houston, Texas, American Association of Stratigraphic Palynologists Foundation, p. 239-241.

Bridge, J.S., Jalfin, G.A., and Georgieff, S.M., 2000, Geometry, lithofacies, and spatial distribution of Cretaceous fluvial sandstone bodies, San Jorge Basin, Argentina: Outcrop analog for the hydrocarbon-bearing Chubut Group: Journal of Sedimentary Research, v. 70, p. 341-359, doi:10.1306/2DC40915-0E47-11D7 $-8643000102 \mathrm{C} 1865 \mathrm{D}$.

Brinkhuis, H., Schouten, S., Collinson, M.E., Sluijs, A., Sinninghe Damsté, J.S., Dickens, G.R., Huber, M., Cronin, T.M., Onodera, J., Takahashi, K., Bujak, J.P., Stein, R., van der Burgh, J., Eldrett, J.S., Harding, I.C., Lotter, A.F., Sangiorgi, F., van Konijnenburg-van Cittert, H., de Leeuw, J.W., Matthiessen, J., Backman, J., and Moran, K., and the Expedition 302 Scientists, 2006, Episodic fresh surface waters in the Eocene Arctic Ocean: Nature, v. 441, p. 606-609, doi:10.1038/nature04692.

Camacho, H.H., 1954, Some upper Cretaceous Foraminifera from Argentina: Contributions from the Cushman Foundation for Foraminiferal Research, v. 5, Part 1, p. 31-35.

Camacho, H.H., 1967, Las transgresiones del Cretácico Superior y Terciario de la Argentina: Revista de la Asociación Geológica Argentina, v. 22, p. 253-280.

Casal, G., Martínez, R., Luna, M., Sciutto, J.C., and Lamanna, M., 2007, Aeolosaurus colhuehuapensis sp. nov.(Sauropoda, Titanosauria) de la Formación Bajo Barreal, Cretácico superior de Argentina: Revista Brasileira de Paleontologia, v. 10, p. 53-62, doi: 10.4072/rbp.2007.1.05.

Casal, G., Candeiro, C.R.A., Martínez, R., Ivany, E., and Ibiricu, L., 2009, Dientes de Theropoda (Dinosauria, Saurischia) de la Formación Bajo Barreal, Cretácico Superior, Provincia del Chubut, Argentina: Geobios, v. 42, p. 553-560, doi:10.1016/j.geobios.2009.03.002.

Case, J.A., and Woodburne, M.O., 1986, South American marsupials: A successful crossing of the CretaceousTertiary boundary: Palaios, v. 1, p. 413-416, doi: $10.2307 / 3514478$

Cecil, M.R., Gehrels, G., Ducea, M.N., and Patchett, P.J., 2011, U-Pb-Hf characterization of the central Coast Mountains batholith: Implications for petrogenesis and crustal architecture: Lithosphere, v. 3, p. 247-260, doi: 10.1130/L134.1.

Chebli, G., and Serraiotto, A., 1974, Nuevas localidades del Paleoceno marino en la región central de la Provincia del Chubut: Revista de la Asociación Geológica Argentina, v. 29, p. 311-318

Cione, A.L., Gouiric-Cavalli, S., Gelfo, J.N., and Goin, F.J., 2011, The youngest non-lepidosirenid lungfish of South America (Dipnoi, latest Paleocene-earliest Eocene, Argentina): Alcheringa, v. 35, p. 193-198, doi: 10.1080/03115518.2010.489418.

Clyde, W.C., Ting, S., Snell, K.E., Bowen, G.J., Tong, Y., Koch, P.L., Li, Q., and Wang, Y., 2010, New paleomagnetic and stable isotope results from the Nanxiong Basin, China: Implications for the $\mathrm{K} / \mathrm{T}$ boundary and the timing of Paleocene mammalian turnover: The Journal of Geology, v. 118, p. 131-143, doi:10.1086/649893.

Comer, E.E., 2011, Depositional environments of Paleocene plant localities within estuarine facies of the Salamanca Formation, Chubut Province, Argentina, [M.S thesis]: University Park, Pennsylvania, Pennsylvania State University, $148 \mathrm{p}$.

de Paula Couto, C., 1952, Fossil mammals from the beginning of the Cenozoic in Brazil: Condylarthra, Litopterna, Xenungulata and Astrapotheria: Bulletin of the American Museum of Natural History, v. 99, p. $359-394$

Dunn, R.E., Madden, R.H., Kohn, M.J., Schmitz, M.D., Strömberg, C.A.E., Carlini, A.A., Ré, G.H., and
Crowley, J., 2012, A new chronology for middle Eocene-early Miocene South American Land Mamma Ages: Geological Society of America Bulletin, v. 125 , p. 539-555, doi:10.1130/B30660.1.

Escapa, I.H., Iglesias, A., Wilf, P., and Cúneo, N.R., 2013, Oldest macrofossil record of Agathis (Araucariaceae), early Paleocene of Patagonia, Argentina, and its evolutionary significance: Botany, Abstract 378 .

Feruglio, E., 1949, Descripción Geológica de la Patagonia, Vol. II: Dirección General de Yacimientos Petrolíferos Fiscales (YPF), Buenos Aires, $349 \mathrm{p}$

Figari, E., Strelkov, E., Laffitte, G., Cid De La Paz, M.S., Courtade, S., Celaya, J., Vottero, A., Lafourcade, P., Martinez, R., and Villar, H., 1999, Los sistemas petroleros de la Cuenca del Golfo San Jorge: Síntesis estructural, estratigráfica y geoquímica: Buenos Aires, $4^{\circ}$ Congreso de Exploración y Desarrollo de Hidrocarburos, p. 197-237.

Fitzgerald, M.G., Mitchum, R.M., Jr., Uliana, M.A., and Biddle, K.T., 1990, Evolution of the San Jorge Basin, Argentina (1): American Association of Petroleum Geologists Bulletin, v. 74, p. 879-920.

Flynn, J.J., and Swisher, C.C., III, 1995, Cenozoic South American Land Mammal Ages: Correlation to global geochronologies, in Berggren, W.A., Kent, D.V., Aubry, M.-P., and Hardenbol, J., eds., Geochronology, Time Scales and Global Stratigraphic Correlation: A Unified Framework for an Historical Geology: SEPM (Society for Sedimentary Geology) Special Publication 54, p. 317-333, doi:10.2110/pec.95.04.0317.

Foix, N., Paredes, J.M., and Giacosa, R.E., 2012, Upper Cretaceous-Paleocene extensional phase in the Golfo San Jorge basin (Argentina): Growth-fault model, paleoseismicity and paleostress analysis: Journal of South American Earth Sciences, v. 33, p. 110-118, doi: 10.1016/j.jsames.2011.07.005

Forasiepi, A.M., and Martinelli, A.G., 2003, Femur of a monotreme (Mammalia, Monotremata) from the early Paleocene Salamanca Formation of Patagonia, Argentina: Ameghiniana, v. 40, p. 625-630.

Frenguelli, J., 1936, El Banco Verde de Paso Niemann del Río Chico en el Chubut y sus diatomeas: Revista de Museo de la Plata, Tomo I, Sección Geología, p. 3-65.

Gehrels, G.E., Valencia, V.A., and Ruiz, J., 2008, Enhanced precision, accuracy, efficiency, and spatial resolution of U-Pb ages by laser ablation-multicollector-inductively coupled plasma-mass spectrometry: Geochemistry Geophysics Geosystems, v. 9, Q03017.

Gelfo, J.N., 2007, The "condylarth" Raulvaccia peligrensis (Mammalia: Didolodontidae) from the Paleocene of Patagonia, Argentina: Journal of Vertebrate Paleontology, v. 27, p. 651-660, doi:10.1671/0272-4634 (2007)27[651:TCRPMD]2.0.CO;2.

Gelfo, J.N., and Pascual, R., 2001, Peligrotherium tropicalis (Mammalia, Dryolestida) from the early Paleocene of Patagonia, a survival from a Mesozoic Gondwanan radiation: Geodiversitas, v. 23, p. 369-379.

Gelfo, J.N., Ortiz-Jaureguizar, E., and Rougier, G.W 2007, New remains and species of the "condylarth" genus Escribania (Mammalia: Didolodontidae) from the Palaeocene of Patagonia, Argentina: Earth and Environmental Science Transactions of the Royal Society of Edinburgh, v. 98, p. 127-138, doi:10.1017 /S1755691007006081.

Gelfo, J.N., López, G.M., and Bond, M., 2008, A New Xenungulata (Mammalia) from the Paleocene of Patagonia, Argentina: Journal of Paleontology, v. 82, p. 329-335, doi:10.1666/06-099.1.

Gelfo, J.N., Goin, F.J., Woodburne, M.O., and Muizon, C.D., 2009, Biochronological relationships of the earliest South American Paleogene mammalian faunas: Palaeontology, v. 52, p. 251-269, doi:10.1111/j.1475 $-4983.2008 .00835 . x$.

Gradstein, F.M., Ogg, J.G., Schmitz, M., and Ogg, G., 2012 The Geologic Time Scale 2012: Oxford, UK, Elsevier, $1176 \mathrm{p}$.

Gurovich, Y., 2008, Additional specimens of sudamericid (Gondwanatheria) mammals from the early Paleocene of Argentina: Palaeontology, v. 51, p. 1069-1089, doi: 10.1111/j.1475-4983.2008.00805.x.

Ibiricu, L.M., Martínez, R.D., Lamanna, M.C., Casal, G.A Luna, M., Harris, J.D., and Lacovara, K.J., 2010, A 
medium-sized ornithopod (Dinosauria: Ornithischia) from the Upper Cretaceous Bajo Barreal Formation of Lago Colhué Huapi, southern Chubut Province, Argentina: Annals of Carnegie Museum, v. 79, p. 39-50, doi: 10.2992/007.079.0103.

Iglesias, A., 2007, Estudio paleobotánico, paleoecológico y paleoambiental en secuencias de la Formación Salamanca, del Paleoceno Inferior en el sur de la Provincia de Chubut, Patagonia, Argentina [Ph.D. thesis, unpublished]: La Plata, Argentina, Universidad Nacional de La Plata, 244 p.

Iglesias, A., Wilf, P., Johnson, K.R., Zamuner, A.B., Cúneo, N.R., Matheos, S.D., and Singer, B.S., 2007, A Paleocene lowland macroflora from Patagonia reveals significantly greater richness than North American analogs: Geology, v. 35, p. 947-950, doi:10.1130/G23889A.1.

Jaffey, A.H., Flynn, K.F., Glendenin, L.E., Bentley, W.C., and Essling, A.M., 1971, Precision measurement of half-lives and specific activities of ${ }^{235} \mathrm{U}$ and ${ }^{238} \mathrm{U}$ : Physical Review C: Nuclear Physics, v. 4, p. 1889-1906, doi:10.1103/PhysRevC.4.1889.

Jiang, S., Bralower, T.J., Patzkowsky, M.E., Kump, L.R., and Schueth, J.D., 2010, Geographic controls on nannoplankton extinction across the Cretaceous/Palaeogene boundary: Nature Geoscience, v. 3, p. 280-285, doi: 10.1038 /ngeo775.

Kennett, J.P., and Stott, L.D., 1991, Abrupt deep-sea warming, palaeoceanographic changes and benthic extinctions at the end of the Palaeocene: Nature, v. 353 p. 225-229, doi:10.1038/353225a0.

Kirschvink, J.L., 1980, The least-squares line and plane and the analysis of paleomagnetic data: Geophysical Journal of the Royal Astronomical Society, v. 62, p. 699718, doi:10.1111/j.1365-246X.1980.tb02601.x.

Kominz, M.A., Browning, J.V., Miller, K.G., Sugarman, P.J., Mizintseva, S., and Scotese, C.R., 2008, Late Cretaceous to Miocene sea-level estimates from the New Jersey and Delaware coastal plain coreholes: An error analysis: Basin Research, v. 20, p. 211-226, doi: 10.1111/j.1365-2117.2008.00354.x.

Krause, J.M., and Piña, C.I., 2012, Reptilian coprolites in the Eocene of central Patagonia, Argentina: Journal of Paleontology, v. 86, p. 527-538, doi:10.1666/11-075.1.

Kuiper, K.F., Deino, A., Hilgen, F.J., Krijgsman, W., Renne, P.R., and Wijbrans, J.R., 2008, Synchronizing rock clocks of Earth history: Science, v. 320, p. 500-504, doi:10.1126/science.1154339.

Lamanna, M.C., Martinez, R.D., and Smith, J.B., 2002, A definitive abelisaurid theropod dinosaur from the early Late Cretaceous of Patagonia: Journal of Vertebrate Paleontology, v. 22, p. 58-69, doi:10.1671/0272-4634 (2002)022[0058:ADATDF]2.0.CO;2.

Legarreta, L., and Uliana, M.A., 1994, Asociaciones de fósiles y hiatos en el Supracretácico-Neógeno de Patagonia: Una perspectiva estratigráfico-secuencial: Ameghiniana, v. 31, p. 257-281.

Legarreta, L., Uliana, M.A., and Torres, M., 1990, Secuencias deposicionales Cenozoicas de Patagonia Central Sus relaciones con las asociaciones de mamíferos terrestres y episodios marinos epicontinentales: Concepción, $3^{\circ}$ Simposio del Terciario de Chile, p. 135-176.

Loeblich, A.R., and Tappan, H., 1988, Foraminiferal Genera and their Classification: New York, Van Nostrand Reinhold, 2 vol., 970 and 847 p.

Lowrie, W., 1990, Identification of ferromagnetic minerals in a rock by coercivity and unblocking temperature properties: Geophysical Research Letters, v. 17 p. 159-162, doi:10.1029/GL017i002p00159.

Ludwig, K.R., 2003, User's Manual for Isoplot 3.00: A geochronology toolkit for Microsoft Excel: Berkeley Geochronological Center, Special Publications 4, 70 p

Madden, R.H., Carlini, A.A., Vucetich, M.G., and Kay, R.F., eds., 2010, The Paleontology of Gran Barranca: Evolution and Environmental Change through the Middle Cenozoic of Patagonia: Cambridge, UK, Cambridge University Press, $458 \mathrm{p}$.

Marshall, L.G., Butler, R.F., Drake, R.E., and Curtis, G.H., 1981, Calibration of the beginning of the age of mammals in Patagonia: Science, v. 212, p. 43-45, doi: 10.1126/science. 212.4490 .43 .

Marshall, L.G., Sempere, T., and Butler, R.F., 1997, Chronostratigraphy of the mammal-bearing Paleocene of
South America: Journal of South American Earth Sciences, v. 10, p. 49-70, doi:10.1016/S0895-9811 (97)00005-9.

Martini, E., 1971, Standard Tertiary and Quaternary calcareous nannoplankton zonation, in Tecnosci, E.D., ed., Proceedings of the 2nd International Conference of Planktonic Microfossils, Rome, v. 2, p. 739-785.

Masiuk, V., 1967, Estratigrafía del Rocanense del Puesto Alvarez, curso inferior del Río Chico, Provincia del Chubut: Revista del Museo de La Plata, nueva serie: Paleontología, v. 5, p. 197-258.

Matheos, S.D., Brea, M., Ganuza, D., and Zamuner, A., 2001, Sedimentología y paleoecología del Terciario Inferior en el sur de la Provincia del Chubut, República Argentina: Revista de la Asociación Argentina de Sedimentología, v. 8, p. 93-104.

Matheos, S.D., Brea, M., Zucol, A.F., Prámparo, M., Raigemborn, M.S., Iglesias, A., and Fischer, A., 2005, Análisis paleoambiental de las sedimentitas del Daniano del sector sur de los Lagos Musters y Colhué Huapi (Chubut, Argentina): Actas XVI Congreso Geológico Argentino, T. III, p. 83-90.

Mattinson, J.M., 2005, Zircon U-Pb chemical abrasion ("CA-TIMS") method: Combined annealing and multi-step partial dissolution analysis for improved precision and accuracy of zircon ages: Chemical Geology, v. 220, p. 47-66, doi:10.1016/j.chemgeo.2005.03 011 .

McInerney, F.A., and Wing, S.L., 2011, The PaleoceneEocene Thermal Maximum: A perturbation of carbon cycle, climate, and biosphere with implications for the future: Annual Review of Earth and Planetary Sciences, v. 39, p. 489-516, doi:10.1146/annurev-earth $-040610-133431$.

Méndez, I., 1966, Foraminíferos, edad y correlación estratigráfica del Salamanquense de Punta Peligro $\left(45^{\circ} 30^{\prime} \mathrm{S} ; 67^{\circ} 11^{\prime} \mathrm{W}\right)$, provincia del Chubut: Revista de la Asociación Geológica Argentina, v. 21, p. 127-157.

Min, K., Mundil, R., Renne, P.R., and Ludwig, K.R., 2000, A test for systematic errors in ${ }^{40} \mathrm{Ar} /{ }^{39} \mathrm{Ar}$ geochronology through comparison with $\mathrm{U} / \mathrm{Pb}$ analysis of a $1.1-\mathrm{Ga}$ rhyolite: Geochimica et Cosmochimica Acta, v. 64, p. 73-98, doi:10.1016/S0016-7037(99)00204-5.

Mohr, B.A., and Lazarus, D.B., 1994, Paleobiogeographic distribution of Kuylisporites and its possible relationship to the extant fern genus Cnemidaria (Cyatheaceae): Annals of the Missouri Botanical Garden, v. 81, p. 758-767, doi:10.2307/2399920.

Navarrete, C., Casal, G., and Martinez, R., 2011, Drusilasaura deseadensis gen. et sp. nov., un nuevo titanosaurio (Dinosauria-Sauropoda), de la Formacion Bajo Barreal, Cretácico Superior del norte de Santa Cruz, Argentina: Revista Brasileira de Paleontologia, v. 14, p. 1-14, doi:10.4072/rbp.2011.1.01.

Olsson, R.K., Hemleben, C., Berggren, W.A., and Huber, B.T., eds., 1999, Atlas of Paleocene Planktonic Foraminifera: Smithsonian Contributions to Paleobiology 85, $252 \mathrm{p}$.

Parma, S.G., and Casadío, S., 2005, Upper CretaceousPaleocene echinoids from northern Patagonia, Argentina: Journal of Paleontology, v. 79, p. 1072-1087, doi:10.1666/0022-3360(2005)079[1072:UCEFNP]2.0 .CO 2 .

Pascual, R., Archer, M., Ortiz-Jaureguizar, E., Prado, J.L., Godthelp, H., and Hand, S.J., 1992, First discovery of monotremes in South America: Nature, v. 356, p. 704 706, doi:10.1038/356704a0.

Pascual, R., Goin, F.J., Balarino, L., and Sauthier, D.U., 2002, New data on the Paleocene monotreme Monotrematum sudamericanum, and the convergent evolution of triangulate molars: Acta Palaeontologica Polonica, v. 47 , p. $487-492$.

Pearson, P.N., Olsson, R.K., Huber, B.T., Hemleben, C., and Berggren, W.A., eds., 2006, Atlas of Eocene Planktonic Foraminifera: Cushman Foundation Special Publication $41,513 \mathrm{p}$.

Petriella, B., and Archangelsky, S., 1975, Vegetación y ambiente en el Paleoceno de Chubut: Congreso Argentino de Paleontología y Bioestratigrafía, Tucumán, Argentina, p. 257-270.

Pross, J., and Brinkhuis, H., 2005, Organic-walled dinoflagellate cysts as paleoenvironmental indicators in the
Paleogene: A synopsis of concepts: Paläontologische Zeitschrift, v. 79, p. 53-59, doi:10.1007/BF03021753.

Raigemborn, M.S., Krause, J.M., Bellosi, E., and Matheos, S.D., 2010, Redefinición estratigráfica del grupo Río Chico (Paleógeno Inferior), en el norte de la Cuenca del Golfo San Jorge, Chubut: Revista de la Asociación Geológica Argentina, v. 67, p. 239-256.

Ré, G.H., Geuna, S.E., Vilas, J.F., Madden, R.H., Carlini, A.A., Vucetich, M.G., and Kay, R.F., 2010, Paleomagnetism and magnetostratigraphy of Sarmiento Formation (Eocene-Miocene) at Gran Barranca, Chubut, Argentina, in Madden, R.H., Carlini, A.A., Vucetich, M.G., and Kay, R.F., eds., The Paleontology of Gran Barranca-Evolution and Environmental Change through the Middle Cenozoic of Patagonia: Cambridge, UK, Cambridge University Press, p. 32-58.

Romero, E.J., 1968, Palmoxylon patagonicum n. sp. del Terciario Inferior de la Provincia de Chubut, Argentina: Ameghiniana, v. 5, p. 417-432.

Scafati, L., Melendi, D.L., and Volkheimer, W., 2009, A Danian subtropical lacustrine palynobiota from South America (Bororó Formation, San Jorge Basin, Patagonia-Argentina): Geologica Acta, v. 7, p. 35-61.

Scasso, R.A., Aberhan, M., Ruiz, L., Weidemeyer, S., Medina, F.A., and Kiessling, W., 2012, Integrated bio- and lithofacies analysis of coarse-grained, tidedominated deltaic environments across the Cretaceous/ Paleogene boundary in Patagonia, Argentina: Cretaceous Research, v. 36, p. 37-57, doi:10.1016/j.cretres .2012.02.002

Schmitz, M.D., and Bowring, S.A., 2001, U-Pb zircon and titanite systematics of the Fish Canyon Tuff: An assessment of high-precision $\mathrm{U}-\mathrm{Pb}$ geochronology and its application to young volcanic rocks: Geochimica et Cosmochimica Acta, v. 65, p. 2571-2587, doi:10.1016 /S0016-7037(01)00616-0.

Schmitz, M.D., and Schoene, B., 2007, Derivation of isotope ratios, errors, and error correlations for $\mathrm{U}-\mathrm{Pb}$ geochronology using ${ }^{205} \mathrm{~Pb}^{235} \mathrm{U}-\left({ }^{233} \mathrm{U}\right)$-spiked isotope dilution thermal ionization mass spectrometric data: Geochemistry Geophysics Geosystems, v. 8, p. 1-20, doi:10.1029/2006GC001492.

Schulte, P., Alegret, L., Arenillas, I., Arz, J.A., Barton, P.J., Bown, P.R., Bralower, T.J., Christeson, G.L., Claeys, P., Cockell, C.S., Collins, G.S., Deutsch, A., Goldin, T.J., Goto, K., Grajales-Nishimura, J.M., Grieve, R.A.F., Gulick, S.P.S., Johnson, K.R., Kiessling, W., Koeberl, C., Kring, D.A., MacLeod, K.G., Matsui, T., Melosh, J., Montanari, A., Morgan, J.V., Neal, C.R., Nichols, D.J., Norris, R.D., Pierazzo, E., Ravizza, G., Rebolledo-Vieyra, M., Reimold, W.U., Robin, E., Salge, T., Speijer, R.P., Sweet, A.R., Urrutia-Fucugauchi, J., Vajda, V., Whalen, M.T., and Willumsen, P.S., 2010, The Chicxulub asteroid impact and mass extinction at the Cretaceous-Paleogene boundary: Science, v. 327, p. 1214-1218, doi:10.1126/science. 1177265 .

Simpson, G.G., 1935a, Descriptions of the oldest known South American mammals, from the Río Chico Formation: American Museum Novitates 793, 25 p.

Simpson, G.G., 1935b, Occurrence and relationships of the Río Chico fauna of Patagonia: American Museum Novitates $818,21 \mathrm{p}$

Simpson, G.G., 1950, History of the fauna of Latin America: American Scientist, v. 38, p. 361-389.

Simpson, G.G., 1980, Splendid Isolation: The Curious History of South American Mammals: New Haven, Connecticut, Yale University Press, 275 p.

Sluijs, A., and Brinkhuis, H., 2009, A dynamic climate and ecosystem state during the Paleocene-Eocene Thermal Maximum: Inferences from dinoflagellate cyst assemblages on the New Jersey Shelf: Biogeosciences, v. 6 , p. 1755-1781, doi:10.5194/bg-6-1755-2009.

Sluijs, A., Pross, J., and Brinkhuis, H., 2005, From greenhouse to icehouse: Organic-walled dinoflagellate cysts as paleoenvironmental indicators in the Paleogene: Earth-Science Reviews, v. 68, p. 281-315, doi:10.1016 /j.earscirev.2004.06.001

Sluijs, A., Bowen, G.J., Brinkhuis, H., Lourens, L.J., and Thomas, E., 2007, The Palaeocene-Eocene Thermal Maximum super greenhouse: Biotic and geochemical signatures, age models and mechanisms of global change, in Williams, M., Haywood, A.M., Gregory, 
F.J., and Schmidt, D.N., eds., Deep-Time Perspectives on Climate Change: Marrying the Signal from Computer Models and Biological Proxies: The Micropalaeontological Society Special Publications: Bath, UK, The Geological Society of London, p. 323-349.

Smith, M.E., Singer, B.S., Carroll, A.R., and Fournelle, J.H., 2006, High-resolution calibration of Eocene strata: ${ }^{40} \mathrm{Ar} /{ }^{39} \mathrm{Ar}$ geochronology of biotite in the Green River Formation: Geology, v. 34, p. 393-396, doi:10.1130 /G22265.1.

Somoza, R., Cladera, G., and Archangelsky, S., 1995, Una nueva tafoflora Paleocena de Chubut, Patagonia: Su edad y ambiente de depositación: $6^{\circ}$ Congreso Argentino de Paleontología y Bioestratigrafía, Trelew, Argentina, p. 265-269.

Spalletti, L.A., and Franzese, J.R., 2007, Mesozoic paleogeography and paleoenvironmental evolution of Patagonia (southern South America), in Gasparini, Z., Salgado, L., and Coria, R.A., eds., Patagonian Mesozoic Reptiles: Bloomington, Indiana University Press, p. 29-49.

Steiger, R.H., and Jäger, E., 1977, Subcommission on geochronology: Convention on the use of decay constants in geo- and cosmochronology: Earth and Planetary Science Letters, v. 36, p. 359-362, doi:10.1016/0012 $-821 X(77) 90060-7$

Sterli, J., and de la Fuente, M.S., 2012, New evidence from the Palaeocene of Patagonia (Argentina) on the evolution and palaeo-biogeography of Meiolaniformes (Testudinata, new taxon name): Journal of Systematic Palaeontology, doi:10.1080/14772019.2012.708674

Sylwan, C.A., 2001, Geología de la Cuenca del Golfo San Jorge, Argentina: Journal of Iberian Geology, v. 27, p. 123-158.
Tauxe, L., ed., 1998, Paleomagnetic Principles and Practice: Dordrecht, Netherlands, Kluwer, 300 p.

Tryon, R.M., Tryon, A.F., and Hodge, W.H., 1982, Ferns and Allied Plants with Special Reference to Tropical America: New York, Springer-Verlag, 857 p.

Vajda, V., and McLoughlin, S., 2007, Extinction and recovery patterns of the vegetation across the CretaceousPalaeogene boundary-A tool for unravelling the causes of the end-Permian mass-extinction: Review of Palaeobotany and Palynology, v. 144, p. 99-112, doi: 10.1016/j.revpalbo.2005.09.007.

van Geel, B., and Grenfell, H.R., 1996, Green and bluegreen algae-spores of Zygnemataceae, in McGregor, D.C., and Jansoniu, J., eds., Palynology: Principles and Applications: Dallas, Texas, American Association of Stratigraphic Palynologists Foundation, p. 173-179.

Watson, G.S., 1956, A test for randomness of directions: Monthly Notices of the Royal Astronomical Society Geophysical, v. 7, Supplement, p. 160-161.

Wilf, P., Cúneo, N.R., Escapa, I.H., Pol, D., and Woodburne, M.O., 2013, Splendid and seldom isolated: The paleobiogeography of Patagonia: Annual Review of Earth and Planetary Sciences, v. 41, p. 561-603, doi:10.1146 /annurev-earth-050212-124217.

Williams, G.L., Brinkhuis, H., Pearce, M.A., Fensome, R.A., Weegink, J.W., and Exon, N.F., 2004, Southern Ocean and global dinoflagellate cyst events compared: Index events for the Late Cretaceous-Neogene, in Exon, N.F., Kennett, J.P., and Malone, M.J., eds., The Tasmanian Gateway: Cenozoic Climatic and Oceanographic Development: Proceedings of the Ocean Drilling Program, Scientific Results: College Station, Texas, Ocean Drilling Program, v. 189, p. 1-98.
Wolfe, J.A., 1987, Late Cretaceous-Cenozoic history of deciduousness and the terminal Cretaceous event: Paleobiology, v. 13, p. 215-226.

Woodburne, M.O., Goin, F.J., Bond, M., Carlini, A.A., Gelfo, J.N., López, G.M., Iglesias, A., and Zimicz, A.N., 2013, Paleogene land mammal faunas of South America: A response to global climatic changes and indigenous floral diversity: Journal of Mammalian Evolution, doi:10.1007/s 10914-012-9222-1.

Zachos, J.C., Pagani, M., Sloan, L., Thomas, E., and Billups, K., 2001, Trends, rhythms, and aberrations in globa climate 65 Ma to Present: Science, v. 292, p. 686-693, doi:10.1126/science.1059412.

Zamaloa, M.C., and Andreis, R.R., 1995, Asociación palinológica del Paleoceno temprano (Formación Salamanca) en Ea. Laguna Manantiales, Santa Cruz, Argentina: $4^{\circ}$ Congreso Argentino Paleontología y Bioestratigrafía Trelew, Argentina, p. 301-305.

Zetter, R., Hofmann, C.C., Draxler, I., Durango de Cabrera, J., Vergel, M., and Vervoorst, F., 1999, A rich middle Eocene microflora at Arroyo de los Mineros, near Cañadón Beta, NE Tierra del Fuego Province, Argentina: Abhandlungen der Geologischen Bundesanstalt, v. 56 , p. $439-460$

Science Editor: Christian KoEberL Associate Editor: Walter Alvarez

MAnUSCRIPT ReCEIVEd 25 APRIL 2013

Revised Manuscript Received 3 September 2013

MANusCRIPT ACCEPTED 20 November 2013

Printed in the USA 